\title{
CONFIGURING VIRTUE: \\ THE EMERGENCE OF ABSTRACTION, ALLEGORESIS AND EMBLEM IN SWEDISH FIGURAL SCULPTURE OF THE SEVENTEENTH CENTURY
}

In 1642, the Amsterdam engraver, Crispijn de Passe the Younger published an unusual emblem book called Den Onderganck des Roomschen Arents door den Noordschen Leeuw ("The Overthrow of the Roman Eagle by the Northern Lion"). ${ }^{1}$ This work was a hagiographical memorial of the brief, but glorious, intervention of the Swedish king Gustavus Adolphus in the Thirty Years' War published ten years after his death, and some seven years after that of the book's author, the preacher Bartholomaeus Hulsius. ${ }^{2}$ In one of the book's twenty-nine plates, De Passe presents us with a prospect of Gustavus Adolphus' mausoleum in Stockholm (Fig. 1). It is depicted as an effigial monument with the figure of the king recumbent on top of a chest-tomb. He rests under a broad canopy supported by six female statues which act as a species of caryatid. Four of the statues are fully visible to the viewer, and by their attributes are easily readable as personifications of the Cardinal Virtues. From left to right, we find Iustitia (Justice) with sword and scales, Fortitudo (Fortitude) with a column, Temperantia (Temperance) diluting a flagon of wine with water, and

DOI: http://dx.doi.org/10.12697/BJAH.2015.9.05

1 Bartholomaeus Hulsius, Den Onderganck des Roomschen Arents door den Noordschen Leeuw (Amsterdam: Crispijn de Passe the Younger, 1642).

2 Concerning this work, see Simon McKeown, "A Reformed and Godly Leader: Bartholomaeus Hulsius's Typological Emblems in Praise of Gustavus Adolphus”, Reformation 5 (2000), 55-101. 


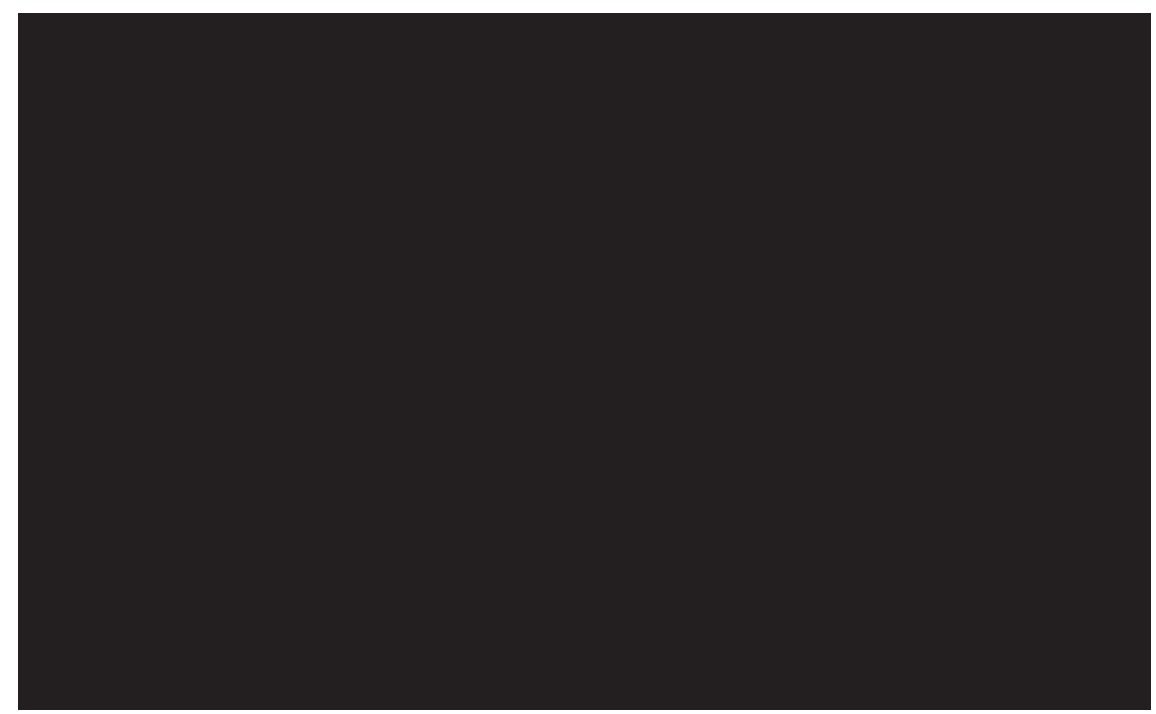

Fig. 1. Emblem 16, Bartholomaeus Hulsius, Den Onderganck des Roomschen Arents door den Noordschen Leeuw, Amsterdam, 1642. Photo: Courtesy of the Department of Special Collections, University of Glasgow Library.

Prudentia (Prudence) with her mirror and serpent. The subscriptio of De Passe's emblem considers the Swedish king to have been as rare in his qualities as the phoenix, which is depicted at the foot of the tomb in its fiery nest; and in his prose commentary Hulsius expectantly suggests that General Gustavus Horn might represent the rebirth of Swedish hopes from the funeral pyre of the king. ${ }^{3}$ The statues of the Virtues stand sentinel over the king's resting place, and through associative proximity to the king's effigy, intimate that they are embodiments and projections of those inner moral qualities which in life were discernible only through the king's words and deeds.

Neither Hulsius nor De Passe had, in fact, visited Stockholm to see Gustavus Adolphus' tomb in the Riddarholmskyrkan, and the image we find in the emblem book is wholly suppositious. In truth, the resting place of the Swedish king was quite unlike the imaginings of De Passe's engraving. There was no carved marble chest-tomb, no effigy of the king in repose, and no canopied figures moralizing his mortal remains. Presumably unaware of or unconcerned by such veracities, De Passe modelled his conception upon the tomb of a comparable Protestant

3 Hulsius, Den Onderganck, 46-47. 
hero rather closer to home, that of William of Orange, also called William the Silent, in the Nieuwe Kerk in Delft. ${ }^{4}$ It was in that city that William was shot by a Catholic assassin in 1584, and where he was later buried, since his native Breda was under Spanish occupation. His splendid marble tomb was commissioned nearly thirty years later to mark the signing of the Twelve Years' Truce which signalled Spain's exhaustion in its struggles with the Dutch. The tomb's sculptor was Hendrik de Keyser who worked in the new Baroque style, expressed particularly through the flexuous animation of the four supporting allegorical figures representative of Iustitia, Fortitudo, Libertas (Liberty), and Religio (Religion, specifically, the Reformed Religion). When the tomb was unveiled in 1623 , it was quickly valued as a patriotic touchstone for the newly established nation (Fig. 2). ${ }^{5}$ Similar reverence surrounded the burial place of Gustavus Adolphus, though the setting was altogether less imposing. The Swedish authorities, under the direction of the king's old chancellor Axel Oxenstierna, had arranged for a mortuary chapel to be built onto the south-east side of the Riddarholmskyrkan's chancel. The king's body, far from resting in a marble tomb staffed by allegorical figures, was laid in a block-tin casket chased and ornamented with armorial symbols, and placed on a modest plinth in a vault beneath the chapel, which was left completely empty. ${ }^{6}$ The allegorical sophistication of De Keyser's memorial to William the Silent shared no stylistic parallels with the conditorium Gustavi Adolphi.

From an art historical perspective, it is interesting to observe how ready De Passe was to apportion to Gustavus Adolphus the kind of allegorical apotheosis that must have seemed natural perorations on the king's public and private qualities. The visual vocabulary of the Virtues and similar prosopopoeic figures provided the evident solution to this desire to body forth the king's abstract qualities, and would have been as second nature to an Amsterdam engraver like De Passe with long

4 See: Cicely V. Wedgwood, William the Silent: William of Nassau, 1533-1584 (London: Jonathan Cape, 1944), 248-253.

5 See, for example, E. P. Richardson, "The Tomb of William the Silent by Emanuel de Witte", Bulletin of the Detroit Institute of Arts of the City of Detroit 21 (1942), 62-64. De Keyser may have been conscious of the tomb of Henri II and Catherine de Medici designed and executed by Francesco Primaticcio, Ponce Jacquio and Germain Pilon for the Basilica of St. Denis between 1560 and 1573: concerning this tomb, see Anthony Blunt, Art and Architecture in France, 1500-1700 (Harmondsworth: Penguin, 1953), 60-61, 98-100.

6 See Riddarholmskyrkan i Stockholm. Konsthistoriskt inventarium, ed. by Sigurd Curman and Johnny Roosval (Stockholm: Generalstaben Litografiska Anstalts Förlag, 1937), 393-396. 


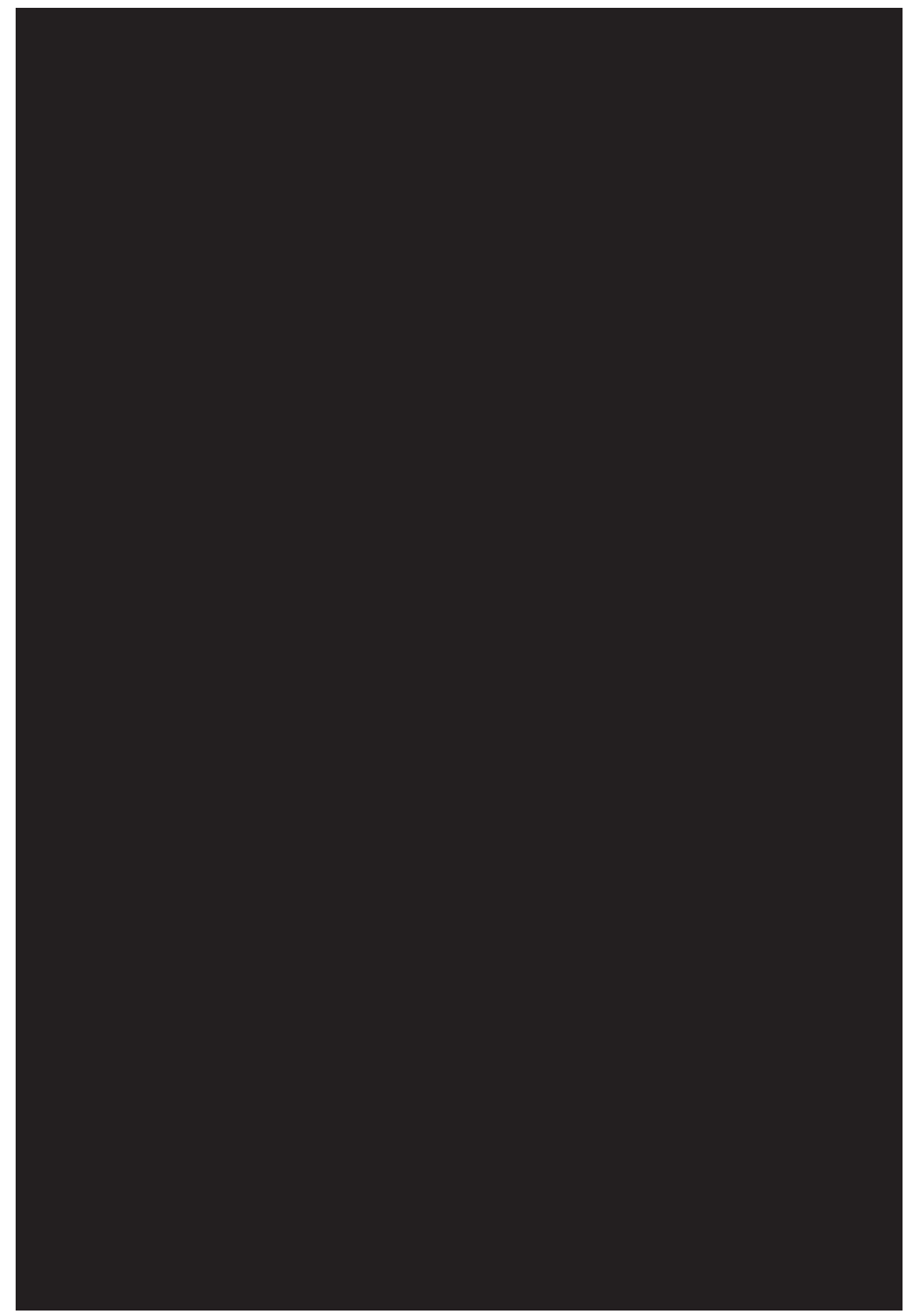

Fig. 2. Hendrik de Keyser, tomb of William the Silent, completed 1623; Nieuwe Kirk, Delft. Photo: Simon McKeown. 
experience in furnishing allegorical plates. His expectation that the emblematic and allegorical conceits interwoven throughout Den Onderganck should be widely understood conveys well the extent of the cultural literacy of the Low Countries in the first half of the seventeenth century. It is possible to extrapolate, too, something of the Swedish cultural environment of the 1630s from the contrasting evidence presented by the simpler furnishing of Gustavus Adolphus' mausoleum. ${ }^{7}$

De Passe's assumptions about levels of cultural acquisition in Sweden serve as an introduction to the wider problem of identifying the "moment" of the Swedish Renaissance, and just when it becomes viable to apply that term to the Swedish seventeenth-century experience. ${ }^{8}$ Swedish historiography has traditionally suggested that the renovation and reform of the arts and letters in the early modern era was negligible in the reign of Gustav Vasa (1523-1560) and only falteringly felt in the reigns of his sons, Erik XIV (1560-1568) and Johan III (1568-1592). It is generally suggested that the assimilation of Renaissance ideas and values was one dimension of a very much wider cultural process of "Europeanization" that arose from Sweden's participation in the Thirty Years' War and the power and prowess it brought. This view has been finessed and refined in various studies, but the processes by which artistic ideas and innovations from continental Europe leached into the fabric of Swedish cultural expression remain only partially understood.

My aim in this paper is to contribute a little more to this understanding through a close focus on the Virtues, both Cardinal and Theological, and investigate how these venerable vehicles of classical and Christian thought became adopted and assimilated into the visual sphere of the

7 A tomb of considerable elaboration with an entablature supported on fluted Corinthian columns was erected for the burial place of Jesper Mattsson Kruus in the Storkyrkan, Stockholm, in 1628. See Göran Axel-Nilsson, Dekorativ stenhuggarkonst i yngre vasastil (Stockholm: Stockholms kommunalförvaltning, 1950), 58-59.

8 Concerning these historiographical questions see, for example, Peter Gillgren, Vasarenässansen. Konst och identitet i 1500-talets Sverige (Lund: Signum, 2009); Inga Lena Ångström-Grandien, “The Reception of the Classical Ideal in Swedish Sixteenth-Century Art and Architecture", The Problem of [the] Classical Ideal in the Art and Architecture of the Countries around the Baltic Sea, ed. by Krista Kodres, Piret Lindpere and Eva Näripea, Estonian Academy of Arts Proceedings (Tallinn: Eesti Kunstiakadeemia, 2003), 32-54; and Simon McKeown, "Reading and Writing the Swedish Renaissance", Renaissance Studies 23.2 (2009), 141-150. 
Swedish Renaissance. ${ }^{9}$ Such allegorical types as the Virtues may be seen as typical manifestations of the dual intellectual relativism of the Italian Renaissance, a marriage of Christian iconography and classical tropes that answered the growing curiosity for the culture of antiquity and the syncretic impulse born out of humanism. ${ }^{10}$ Important scholars of the last century traced lines of continuity in the presentation of such abstractions from the late classical era into the Christian Middle Ages, but any sense of a cultural continuum dissolves in the face of the evidence in Sweden. ${ }^{11}$ Very little trace of such syncretic iconography is discernible here, and where we do encounter images of the Virtues, they are atypical of the vernacular repertoire of ecclesial art, and comparatively late expressions of visual ideas that flourished in other parts of Europe from late antiquity. ${ }^{12}$ To keep within manageable bounds, I shall largely confine my discussion to manifestations of the Virtues as found in Swedish figural sculpture, not only as the material evidence in this form has proven to be durable, but because it offers both a substantial and representative corpus for analysis. Much of the material under review takes the form of sepulchral sculpture, an area of cultural pro-

9 Concerning artistic representations of the Cardinal Virtues, see, among many others, Adolf Katzenellenbogen, Allegories of the Virtues and Vices in Medieval Art from Early Christian Times to the Thirteenth Century (London: The Warburg Institute, 1939); and Jennifer O'Reilly, Studies in the Iconography of the Virtues and Vices, diss. University of Nottingham, 1972; for a recent study of the intellectual background, see Istvan P. Bejccy, The Cardinal Virtues in the Middle Ages: A Study in Moral Thought from the Fourth to the Fourteenth Century, Brill Studies in Intellectual History 202 (Leiden: Brill, 2011). Interest in the Virtues in Swedish historiography is attested by a recent interdisciplinary volume of studies edited by Catharina Stenqvist and Marie Lindstedt Cronberg: see Dygder och laster. Förmoderna perspectiv på tillvaron, ed. by Catharina Stenqvist and Marie Lindstedt Cronberg (Lund: Nordic Academic press, 2010).

10 Allegorical abstractions were already present in Hellenistic antiquity, and personifications of Virtues widespread in the Roman era (see, as a locus classicus, Cicero's De Officiis): a good survey of the material is provided in Helen North, "Canons and Hierarchies of the Cardinal Virtues in Greek and Latin Literature", The Classical Tradition: Literary and Historical Studies in Honor of Harry Caplan, ed. by Luitpold Wallach (Ithaca: Cornell University Press, 1966), 165-183. The Virtues gained enormous currency through Prudentius' fifth-century work, Psychomachia, and it was by agency of this text above other sources that the Virtues were transmitted to the Middle Ages. An authoritative exposition of the Virtues is to be found in Thomas Aquinas' Summa theologica, 2.2, where the classical models are fully subsumed into the Christian exegetical tradition.

11 The assimilation of these classical notions into the Christian era is charted with supreme authority in Jean Seznec, The Survival of the Pagan Gods: The Mythological Tradition and its Place in Renaissance Humanism and Art, trans. by Barbara F. Sessions (New York: Pantheon, 1953); see also Erwin Panofsky, Studies in Iconology: Humanistic Themes in the Art of the Renaissance (Oxford: Oxford University Press, 1939), passim. Still useful is C.S. Lewis, The Allegory of Love: A Study in Medieval Tradition (Oxford: Clarendon Press, 1936), particularly, 44-111.

12 A rare exception is discussed in Folke Nordström, Virtues and Vices on the Fourteenth-Century Corbels in the Choir of Uppsala Cathedral (Stockholm: Almqvist and Wiksell, 1956). 
duction in which Sweden remains comparably rich. The combination of Sweden's economic rise in the first part of the seventeenth century, and the corresponding dynastic ambitions of its nobility in response to this enrichment, created ripe conditions for the elaborate memorializing of society's elite. ${ }^{13}$ The siting of such monuments in cathedrals and mortuary chapels has further safeguarded the evidence from the predations of time; we must also consider as a factor in such stability the integrity of Sweden's borders from the invasion of foreign armies over the past two hundred years. Finally, something intrinsic to the demands of the funeral monument meant that figures of the Virtues became popular distillations of the cultural values espoused by the class of society that required such testimonies to define their sovereign character. These are elusive but important ideas I shall return to at the end of the article.

The earliest manifestation of the Virtues in Swedish sculptural art cannot be traced back earlier than the 1580s, and even with this cave-

13 These processes are considered in, inter alia, Bengt Ankarloo, "Europe and the Glory of Sweden: The Emergence of a Swedish Self-Image in the Early Seventeenth Century", Europe and Scandinavia: Aspects of the Process of Integration in the Seventeenth Century, ed. by Göran Rystad, Lund Studies in International History (Lund: Esselte studium, 1983), 237-244; Sven A. Nilsson, "Imperial Sweden: Nation-Building, War and Social Change", The Age of New Sweden, ed. by Arne Losman, Agneta Lundström and Margareta Revera (Stockholm: Livrustkammaren, 1988), 9-39; Margareta Revera, "The Making of a Civilized Nation: Nation-Building, Aristocratic Culture and Social Change", The Age of New Sweden, 103-131; and Göran Rystad, "Expansion and Social Transformation: Sweden's Great Power Experience", The Vasa Dynasty and the Baltic Region: Politics, Religion and Culture, 1560-1660. A Symposium at Kalmar Castle, February 4-6 2000, ed. by Lars Andersson (Kalmar: Kalmar Castle, 2003), 61-68. Sepulchral art has drawn the attention of several scholars working in the visual culture of the Baltic region: see, for example, Allan Ellenius, "The Rhetoric of Virtue: A Note on the Function of Seventeenth-Century Sepulchral Imagery”, Ars naturam adiuvans. Festschrift für Matthias Winner, ed. by Victoria V. Flemming and Sebastian Schütze (Mainz: Philipp von Zabern, 1996), 514-523; Alicija Saar-Kozlowska, "Pomniki grobowe rodziny króla Jana III Wazy w Szwecji i w Polsce", Po obu stronach Baltyku. Wzajemne relacje miedzy Skandynawia a Europa Srodkowa/On the Opposite Sides of the Baltic Sea: Relations between Scandinavia and Central European Countries, ed. by Jan Harasimowicz, Piotr Oszczanowski and Marcin Wislocki (Wroclaw: Uniwersytet Wroclawski and Polskie Towarzystwo Badan Reformacji, 2006), 569-585; Marcin Wislocki, "Szwedzki pulkownik Jacob Mack Duwal i jego kaplica grobowa w kosciele Sw. Mikolaja w Stralsundzie”, Po obu stronach Baltyku, 587-599; Jan Samuelsson, "Om adelns symboliska representation i kyrkorna", Blickar bakåt. Elva uppsatser om ett förgånget nu, ed. by Christina Kjellson, Sven Olofsson and Per Sörlin, Institutionen för humaniora 15 (Härnösand: Mitthögskolan, 2004); and Jenny Nyberg, "'O himmels gyllne pracht” - Familjen Brahe och stormaktstidens adliga begravningar”, Grevars och bönders tempel. En bok om Brahekyrkan på Visingsö, ed. by Robin Gullbrandsson (Jönköping: Jönköpings läns museum, 2013), 257-275. 
at, the evidence for such dating must be approached with caution. ${ }^{14}$ In keeping with what we know about the cultural transfer of continental ideas into Sweden, it seems that the introduction of the Virtues into the Swedish sculptural repertoire was mediated through a Dutch artist, Willem Boy. Boy (1520-1592) had been summoned by Gustav Vasa sometime in the latter 1550s, was responsible for the advent of a new artistic style in sixteenth-century Sweden, served successive Vasa monarchs as portraitist, sculptor, and architect, and influenced the design of many of Sweden's most significant buildings of the age. One such undertaking was the modernization, ordered by Johan III, of the Tre Kronor Castle in Stockholm. Johan III's renovations aimed to refashion this massive medieval bastion into the more gracious lines of a Renaissance palace - in a similar way to the efforts expended on the castles of Kalmar and Gripsholm by Gustav Vasa and Erik XIV. Boy was limited in the scope of what he could achieve because the castle still needed to serve a defensive function; but in at least one of his innovations, he achieved Renaissance grace and elegance.

This was in the gable he built onto the exterior of Tre Kronor's Rikssal, or Hall of State. ${ }^{15}$ Unfortunately, this gable was lost in the fire that consumed the Tre Kronor in 1697, but a general sense of its appearance can be gleaned from a painting made of the castle from the south-west by Govert Camphuysen in 1661. ${ }^{16}$ Camphuysen's painting shows Boy's gable quite clearly; this is confirmed by a detail in a copperplate by Jean le Pautre, an engraver in Erik Dahlbergh's workshop, and produced for

14 Representations of the Virtues in Sweden in the sixteenth century are rare in any medium. We find Prudentia alongside Occasio (Opportunity), Venus and Lucretia on tiny gold stamped motifs found in the spine compartments of books bound in Stockholm by the German immigrant printer Johann Knufflock dating from the 1540s: see Arvid Hedberg, Stockholms bokbindare 1460-1880, Nordiska museets handlingar 36 (Stockholm: Nordiska museet, 1949), 17-25, plates 11-14. Mereth Lindgren notes images of Fides, Fortitudo and Temperantia and other allegorical abstractions among the remarkable ceiling paintings at Glanshammar church in Närke painted in 1589 by "AIR PICT" (probably Anders Jordansson Ryttare). Lindgren's wider survey makes clear how unusual the Glanshammar paintings are in their depiction of the Virtues. See Mereth Lindgren, Att lära och att pryda. Om efterreformatoriska kyrkmålningar i Sverige circa 1530-1630 (Stockholm: Kungl. Vitterhets Historie och Antikvitets Akademien, 1983), 91-97.

15 See: Eyvind Unnerbäck, Vadstena slott från befästning till renässanspalats 1563-1620 (Stockholm: Kungl. Vitterhets Historia och Antikvitets Akademien, 1996), 239-241; and Ångström Grandien, “The Reception of the Classical Ideal in Swedish Sixteenth-Century Art and Architecture", 44. Unnerbäck cites the opinion of Martin Olsson from Stockholms slotts historia, vol. 1 (Stockholm: Norstedts, 1940), 159 , that the essential disposition of statues in this triadic grouping derives from Cornelis Floris' design for the great town hall of Antwerp, built in 1561-1565. See Unnerbäck, Vadstena slott, 239.

16 Govert Camphuysen, "Tre Kronor från Slottsbacken" (1661); the painting is in the collection of Stockholm's Stadsmuseum. 
the latter's Suecia antiqua et hodierna. Le Pautre shows the gable with the caption "Aula Regni vulgo Riks Sahlen" ("The Hall of Kings vulgarly (called) the Hall of State" $).{ }^{17}$ Designed in three ascending tiers, the gable marks an amalgam of the Netherlandish step-gable with the rounded forms of Northern Mannerism. The lowest tier presents two windows capped by rounded pediments flanking a cartouche framing the motto "DEUS PROTECTOR MEUS", a familiar motto, or valspråk, of Gustav Vasa. This gives way to a centred panel with a large relief of the riksvapen, or national coat of arms. To either side we see statues set into niches marked off by twinned columns with Corinthian capitals. These niches are capped by broken rounded pediments topped with pinnacles, while above the coat of arms is a tabernacle with a larger niche and statue. Neither Camphuysen's brush nor Le Pautre's burin are quite so refined so as to allow us to read the identity of the statues precisely, but it would be quite in order for such a group to be an articulation of the Virtues; indeed Camphuysen's image seems to show the central figure holding something in her left hand that might correspond to Iustitia's scales. Moreover, documentary evidence exists suggesting that Boy adorned the Tre Kronor chapel choir with figures of the Virtues. In a letter dated 23rd June 1588, King Johan specifies that "Dygder" form part of a decorative programme. As far as can be ascertained, these constituted representations of Faith and Charity executed in gilded copper. Johan also commissioned fresco paintings of the Virtues for the Grå Salen (Grey Chamber) at Kalmar Castle. These works, which are still discernible today, were carried out by Arent Lambrechts. ${ }^{18}$

It was certainly with an awareness of the Tre Kronor's Renaissance additions that Hans Fleming, another Netherlandish architect active in Sweden, approached the design of the castle of Vadstena on the shore of Lake Vättern in Östergötland. ${ }^{19}$ Between 1602 and 1611 a team of builders and stone-carvers under his direction fashioned a gable on Vadstena's eastern side similar in style and form to the older structure in

17 Unnerbäck, Vadstena slott, 239-240, citing Olsson, Stockholms slotts historia.

18 Inga Lena Ångström, Altartavlor från renässans och barock. Studier i deras ikonografi och stil 1527-1686 (Stockholm: Almqvist \& Wiksell, 1992), 54-55.

19 His name indicates his national origin, and probably came from the town of Namur. Employed by Johan III at Vadstena in 1590 after the death of the Dutch architect Arendt de Roy, Fleming had carried out extensive work on royal buildings throughout the 1580s, and had experience of decorative sandstone carving from earlier periods of work in Lübeck. See Unnerbäck, Vadstena slott, 226. 


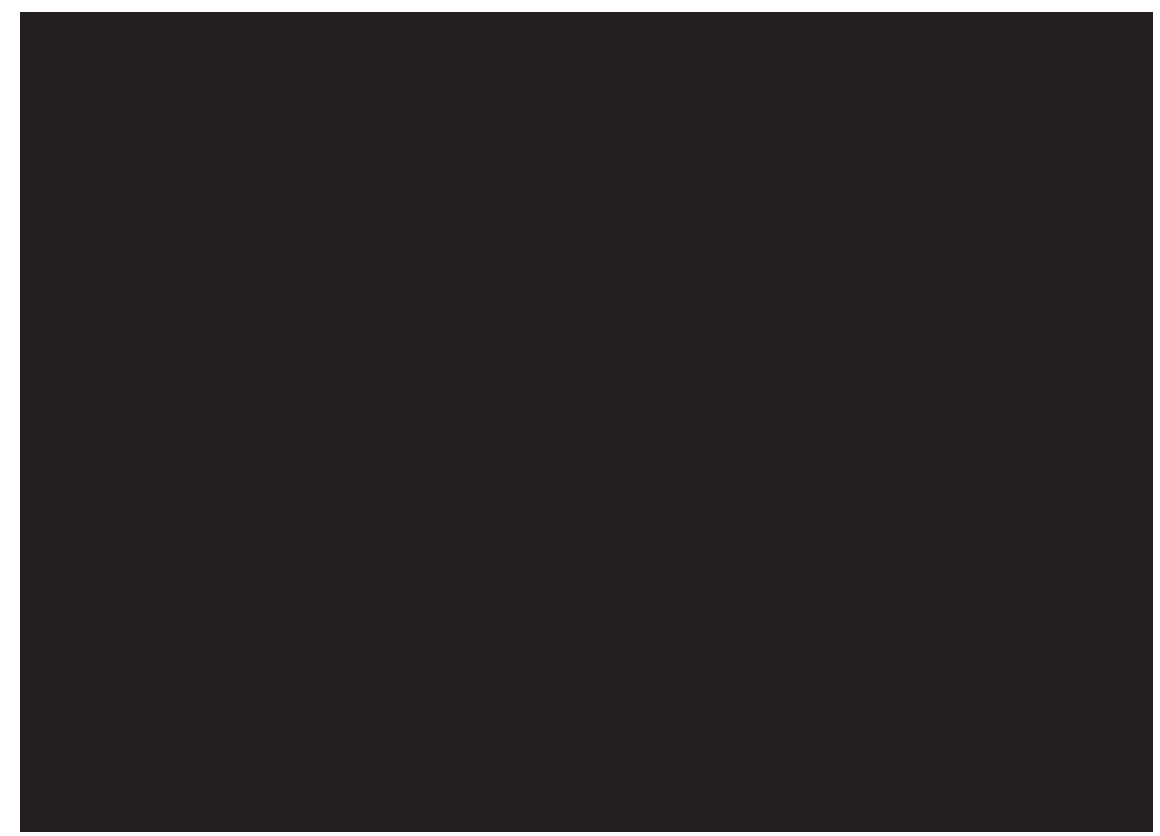

Fig. 3. Hans Fleming, eastern gable of Vadstena Castle, 1602-1611. Photo: Simon McKeown.

Stockholm. ${ }^{20}$ The gable survives today, and within its three niches stand the sculptured figures of Fides (Faith), Spes (Hope), and Caritas (Charity/ Love) (Fig. 3). ${ }^{21}$ Since the famous text from $1{ }^{\text {st }}$ Corinthians states that "the greatest of these is Love (Caritas)", we see Charity occupy the apex of the triadic group surrounded by her traditional attributes of necessitous children.22 A central armorial tablet shows the heraldic arms of Duke Johan of Östergötland, the son of Johan III and Gunilla Bielke, crowned with the ducal coronet and supported by the provincial lion and griffin. In a manner reminiscent of the tomb of William the Silent, the outlying sculptural figures not only embellish the armorial display, but offer comment upon the moral qualities of the duke heraldically signified. The coat of arms is augmented by these allegorical figures into a definition of the private nature of the duke, specifically his pronounced piety.

20 Axel-Nilsson, Dekorativ stenhuggarkonst i yngre Vasastil, 32.

21 The statues on the gable today are replicas placed there in 1974: the original figures are protected from the elements in one of the castle's gun-towers. See Unnerbäck, Vadstena slott, 149.

$221^{\text {st }}$ Corinthians 13, 13. 


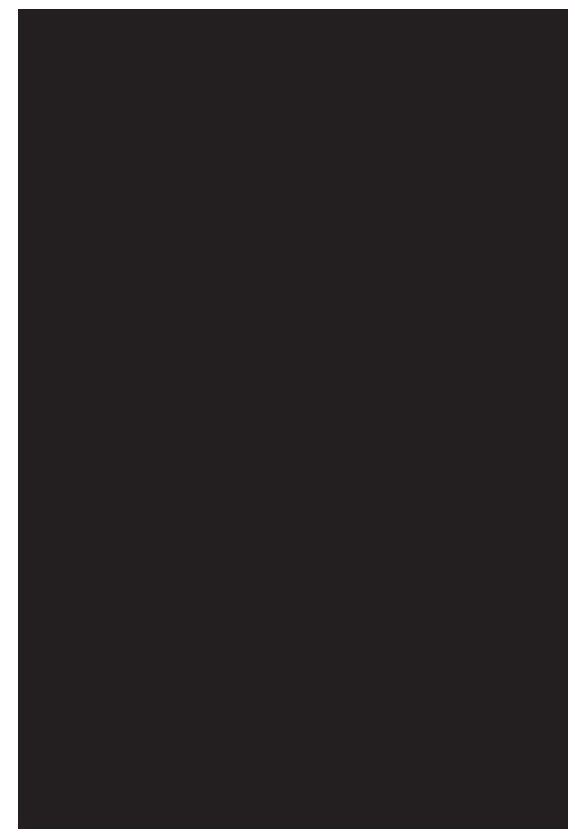

Fig. 4. Unknown architect, western gable of Vadstena Castle, 1620. Photo: Simon McKeown.
The template established on the eastern gable served again in 1620 when a matching gable was erected on the castle's west side (Fig. 4). The same composition involving three statues within niches surrounds a central heraldic display, this time honouring "GARS 1620" ("Gustavus Adolphus Rex Sveciae $\left.1620^{\prime \prime}\right){ }^{23}$ To the left of the arms stands Prudentia with her mirror, and to the right, Fortitudo clasping a column. Completing the ensemble at the apex is Iustitia with her scales. The architects of the western gable have thus extended Vadstena's pantheon of Virtues to include three of the four Cardinal Virtues, excluding Temperance. While the east gable presents the embodiments of religious virtue, the western gable speaks of Gustavus Adolphus' possession of political virtue: wisdom, resolve and even-handed administration of the law. The aggregation of these three Virtues together was by no means arbitrary: their union exemplifies Cicero's well-known discussion in his De officiis ("On Duties") treating of the qualities possessed by the wise and able leader. In Cicero's view, Prudence represents "the full perception and intelligent development of the true"; Justice concerns "the conservation of organized society"; and Fortitude guarantees "the greatness and strength of a noble and invincible spirit". ${ }^{24}$ These qualities of character formed with Temperance the curriculum of the superlative leader: as the Apocryphal Wisdom of Solomon expresses it, "man's excellencies are the fruit (Wisdom) labours to produce; temperance and prudence she teaches, justice and fortitude, and what in

23 Axel-Nilsson, Dekorativ stenhuggarkonst i yngre Vasastil, 35.

24 Cicero, De Officiis I, 15.5. For a discussion of the Virtues and Roman political thought, see Andrew Wallace-Hadrill, "The Emperor and his Virtues", Historia: Zeitschrift für Alte Geschichte 30.3 (1981), 298-323. 
life avails man more?"25 These very figures range round the personal arms of Gustavus Adolphus and insist upon the young king's excellence and probity by means of the visual rhetoric of Renaissance prosopopoeia.

This was an important propagandistic message to impart at this stage of the king's career. The 1610s had been a bruising decade with a humiliating peace struck at Knäred, stinging reparations handed over to Denmark, and scant recognition of the king's very legitimacy in wider Europe. ${ }^{26}$ But by the decade's close, some signs of Gustavus Adolphus' adroit political management were beginning to become evident, and the advantageous Peace of Stolbova that neutralized Muscovy could certainly have been seen as the working of the young king's prudence. ${ }^{27}$ It became possible for rhetoricians to address the king through the agency of the personified Virtues, as evidenced by the Neo-Latin poem Coronarium by the humanist poet Sylvester Johannis Phrygius in 1617.28 Published, as the title suggests, to mark Gustavus Adolphus' coronation in October of that year, Phrygius ventriloquizes a panoply of Virtues who proclaim their allegiance to the king, and promise faithful attendance upon him throughout his reign. The Virtues of Religio, Prudentia, Iustitia, Candor (Openness), Fides, Fortitudo and Liberalitas (Generosity) each declaim a poem in turn, rather like ambassadors presenting their credentials. The poems vary between 12 and 16 lines in length; wittily, the virtue of Temperantia exemplifies her own self-restraint by offering a poem of only eight lines. ${ }^{29}$ Phrygius articulated the Virtues in other panegyrical poems in these years, as for Duke Johan in a poem in Swedish called Ähraskyldige Lijktienst in 1618, and for the long-dead Johan III in his Oratio encomiastica. It is clear that a new Renaissance language of allegorical typology was being used with increasing confidence in the Swedish court of the 1610s: the panegyrical poetry from this time joins

25 The Book of the Wisdom of Solomon, 8, 7.

26 See: Michael Roberts, Gustavus Adolphus: A History of Sweden, 1611-1632, vol. 1 (London: Longmans, 1953), 92-142.

27 Ibidem, 87-91; Sverker Oredsson, Gustav II Adolf (Stockholm: Atlantis, 2007), 64-69.

28 Sylvester Johannis Phrygius, Coronarium hoc Serenissimo et Potentiss. Principi ac Domino, Dn. Gustavo-Adolpho, Suecorum, Gothorum, Vandalorumque \&c. Regi, Magno Principi Finlandiae, Duci Estoniae \& Careliae, Domino Ingriae \&c. in Faustae acclamationis symbolum, devotissimaeque gratulationis inditium, Subjectissime offert Sylvester Iohan. Phrygius, P. Caesarius, Sup. Schaeidviensis. Anno Christiano M.DC.XVII. Octobris (Stockholm: Christopherus Reusnerus, 1617).

29 See: Peter Sjökvist, The Early Latin Poetry of Sylvester Johannis Phrygius, Studia Latina Upsaliensia 31 (Uppsala: Acta Universitatis Upsaliensis, 2007), 67-68; 356-357. 
with the sculptural groups at Vadstena to attest to the regime finding its voice in the new iconographic language of Renaissance emblematics. ${ }^{30}$

Encouragement of these ideas continued to come from overseas. Around 1615 a spectacular funeral monument in black marble and alabaster was erected in the south chapel of Linköping Cathedral. It was intended to mark the burial place of Ture Nilsson Bielke and his wife Margareta Sture. Indeed, it was Margareta (†1617) who was instrumental in arranging the commission and erection of the tomb. It was of a type unseen in Sweden before, and had been carved across the Baltic Sea in the Danzig workshop of the notable Flemish sculptor, Willem van den Blocke. ${ }^{31}$ Van den Blocke is remembered today as the sculptor of the celebrated tomb of Johan III in Uppsala Cathedral, although that tomb was only erected in the early nineteenth century. The Bielke tomb at Linköping, then, was the outstanding witness to his craft in Sweden in the seventeenth century. The tomb shows low-relief effigies of Bielke and his wife lying on a tilted bier (Fig. 5). ${ }^{32}$ Lapidary inscriptions are set amongst a display of columns of the Ionic order, festoons, putt $i$ with inverted torches, heraldic achievements, obelisks of immortality, and the whole edifice crowned with the figure of the resurrected Christ. But between the effigies of the noble dead and the Salvator Mundi stand statues of the three Theological Virtues, Fides, Spes, and Caritas, all executed in Van den Blocke's refined Mannerist idiom. The sculptor's composition compels us to lift our eyes from the figures in repose below our line of sight, to the Virtues at eye level, and on up to the figure of Christ above us, a programmatic enactment of the Bielkes' negotiation of the via salutis through faithful adherence to Christian doctrine. Of course, it may be objected that the three Theological Virtues had formed a traditional part of the repertoire of funereal sculpture since at least the eleventh century, exemplified by the famous tomb of Pope Clement II in

30 The gables at Vadstena seemed to provide the pattern for the exterior of a burial chapel built at Norrsunda church in Uppland in 1633. This was commissioned by Ebba Oxenstierna, sister of the famous chancellor, for her husband Johan Sparre whose armorial weapons are guarded by large relief sculptures of Fides and Spes set within niches. See Axel-Nilsson, Dekorativ stenhuggarkonst $i$ yngre Vasastil, 211-212.

31 See: Torbjörn Fulton, “Skulpturen”, Renässansens konst, Signums svenska konsthistoria 5 (Lund: Signum, 1996), 321-322; Linköpings domkyrka. I. Kyrkobyggnaden. Sveriges kyrkor 200, ed. by Bengt Cnattingius, Ralph Edenheim, Sune Ljungstedt and Marian Ullén (Stockholm: Almqvist and Wiksell, 1987), 28; Axel-Nilsson, Dekorativ stenhuggarkonst i yngre Vasastil, 33-34; 39-41.

32 This tilted effigy on Van den Blocke's tomb is comparable to the similar device deployed by Donatello and Michelozzo for the tomb of Antipope John XXIII (1420s) in the Baptistery in Florence. 


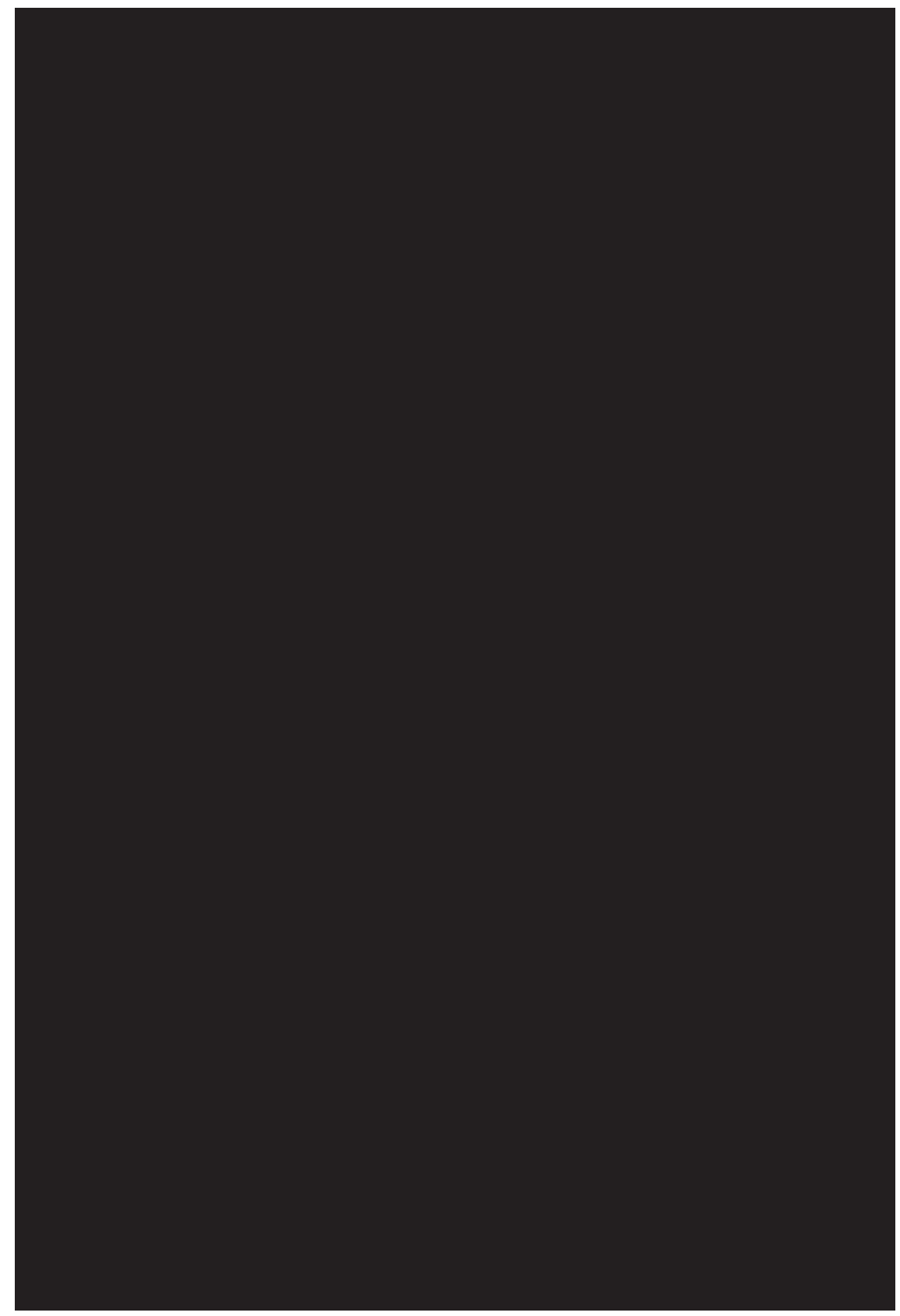

Fig. 5. Willem van den Blocke, tomb of Ture Nilsson Bielke and Margareta Sture, c. 1615; Linköping Cathedral. Photo: Simon McKeown. 
Bamberg, Germany, and that it is therefore unexceptional to find them at Linköping. It is perhaps unusual to observe, however, that the Virtues had not played a role in Swedish tomb sculpture in the Middle Ages nor in the sixteenth century. Something new, therefore, was introduced to the vernacular tradition from Danzig with the Bielke monument.

But there may be more to consider in the Bielke tomb than its iconographic novelty. The Bielkes were one of the great families of the Swedish high nobility, with a pedigree of the utmost lustre stretching back to the end of the Viking era and including incorporation into the Swedish royal family. ${ }^{33}$ Ture Nilsson Bielke enjoyed high office and honour from the earliest age, and his public career began in earnest when he was in his early twenties. His later prominence as a member of the Riksråd and Superintendent of the Treasury (Överste räknemästare) raised him to a position close to the fourth Vasa monarch, Sigismund. When Sigismund was driven out of the kingdom by his uncle, Duke Karl of Södermanland, Bielke was among a handful of high aristocratic councillors left to the Duke's mercy. In fact, he was shown none, and Bielke was beheaded along with four other leading nobles on Maundy Thursday, 1600, in the marketplace at Linköping. ${ }^{34}$ While history has judged the Bloodbath of Linköping as Duke Karl's exercise of brutal Realpolitik, on another level it marked a critical moment of potential dynastic eclipse for the Bielke family. Bielke's widow, who had fled with her children to the estate of Hörningsholm, faced peril, too, as consort of a declared traitor. It is significant to note that Van Den Blocke's monument to Ture Nilsson Bielke was commissioned only after the death of Duke Karl, later Charles IX, in 1611. The entire programme of the monument restores the fallen councillor to full dignity, his head returned to his shoulders in effigy and his innate goodness affirmed by the presiding virtues of Faith, Hope and Charity ${ }^{35}$ Margareta's efforts in furnishing this memorial to her disgraced husband sought to efface the terrible blot upon the dignity of his name, and as widow of a traitor, upon her own reputation, too. The deployment of the Risen Christ and the Theological Virtues can be viewed therefore as a tactic in the rhetorical practice of persuasio, an appeal to posterity for re-evaluation. The reposeful bodies under the aegis of the

33 Gunilla Bielke (1568-1597) had been consort to Johan III.

34 His fellow victims were Erik Sparre, Sten Banér, Gustav Banér and Bengt Falck.

35 The wholeness of the effigy reflects the tradition that Margareta instructed a servant to sew her husband's head back onto his body before he was interred. 


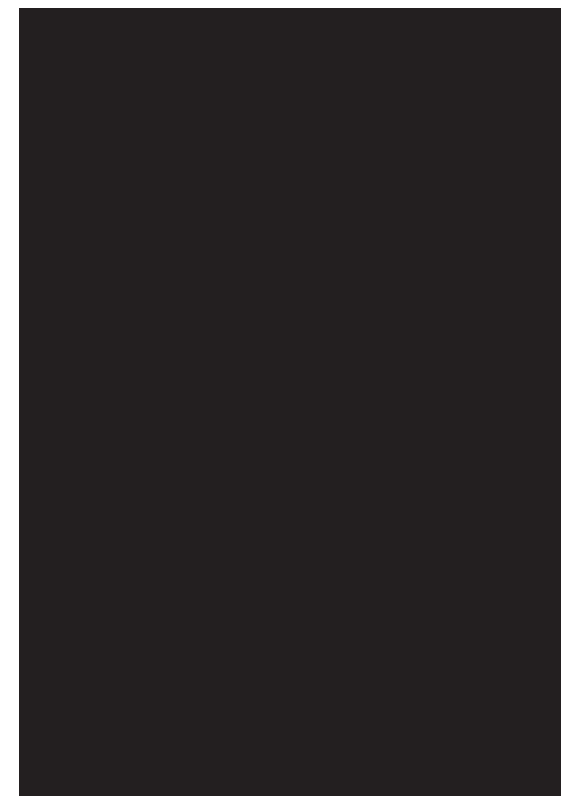

Fig. 6. Aris Claeszon, figure of "Fortitudo" on the tomb of Svante Stenbock and Birgitta Bielke, 1630s; Uppsala Cathedral. Photo: Simon McKeown.

Banér, another victim of the Bloodbath of Linköping, where Iustitia, Fortitudo, Temperantia and Prudentia stand sentinel at the four corners of the tomb's canopy. The same Virtues reappeared a few years later on Claezson's tomb for Gustav's son, Svante Banér, Governor of Riga, in the parish church of Danderyd, north of Stockholm. ${ }^{37}$

The commerce of these humanistic programmes between continental Europe and Sweden, represented by the work of Van den Blocke and Claeszon, was to continue throughout the century and exert clear influence upon vernacular taste. Another manifestation is the remarkable baptistery commissioned for Västerås Cathedral by Anna Gunnarsdotter, the widow of the German-born iron and copper magnate, Simon Depken. The so-called Depken Baptistery (Depkenska Dopkapellet) was installed in the cathedral in 1622, though made in the Lübeck workshop of Heinrich

36 For a sketch of Aris Claeszon's career in Sweden, see "Claeszon, Aris", Svenskt biografiskt lexikon, vol. 8 (Stockholm: Norstedts, 1929), 610.

37 Concerning the former, see Axel-Nilsson, Dekorativ stenhuggarkonst i yngre Vasastil, 69-70; and Fulton, "Skulpturen", 322-324.

Virtues become metonymic of the noble couple's innocence.

The visual rhetoric of the Bielke tomb at Linköping soon found echoes in memorials to the aristocracy across the central belt of Sweden, notably in tombs designed by the immigrant Dutch sculptor, Aris Claeszon. ${ }^{36}$ Prominent examples of his work include the wall tomb for Svante Stenbock and his wife Birgitta Bielke in Uppsala Cathedral that dates from the 1630s. The memorial tablets on the tomb are presided over by Spes and Fortitudo, leaning on anchor and column respectively (Fig. 6). The staffage of Virtues is doubled on another monument by Claeszon elsewhere in the cathedral with his effigy tomb memorializing Gustav 


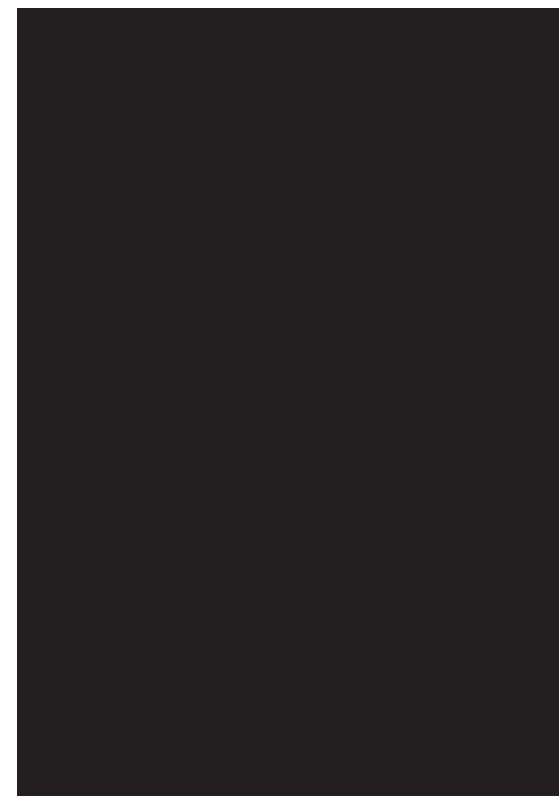

Fig. 7. Heinrich Sextra, figure of "Spes“ on the Depken Baptistery, polychrome wood, 1622; Västerås Cathedral. Photo: Simon McKeown.

Sextra. Depken, who had died in 1620 , was memorialized by one of the most outstanding Renaissance furnishings of the Vasa era, a baptistery of finely carved and polychromed wood enclosing a canopied font. Among its cast of many figures stand the Virtues with gilded hair: alongside the apostles and angels that staff Sextra's work, they stand witness to the life of Grace offered to the recipient of the baptismal rite (Fig. 7).

A similar international influence can also be felt in the chest tomb of Erik Göransson Ulfsparre (+1631) and his widow Beata Oxenstierna (+1652) that stands in the north chapel of Linköping Cathedral. ${ }^{38}$ This was the work of the Silesianborn sculptor, portraitist, and painter, Johan Johansson Werner, who in 1620, in his twenties, had come to Sweden. He is perhaps best known for his work on Magnus Gabriel De la Gardie's chapel at Läckö Castle. ${ }^{39}$ Werner depicts the provincial governor and his wife in effigy on the tomb's surface, while each corner is supported on pilasters faced with high relief sculptures labelled "Temporantia" (sic), "Patientia", "Ivsticia" (sic), "Spes", "Fides", "Charitas", "Prvdentia", and "Fortitvdo" (Figs. 8 \& 9). The side panels of the sarcophagus are adorned with heraldic achievements, and the figures of the Virtues can be seen to replace the role assigned in late medieval tomb sculpture to pleurants, or weepers.

It became more common to find the tombs of the Swedish elite apostrophised by the sculpted forms of the Virtues as the seventeenth century

38 See: Cnattingius et al., Linköpings domkyrka, 28.

39 See: Ingrid Rosell, Läckö slottskyrka. Sveriges kyrkor 198 (Stockholm: Almqvist and Wiksell, 1985), 39, 59, 79. Although Werner was commissioned by De la Gardie to carve sixteen large statues of apostles and other figures, his death in 1656 meant that the work passed to his son, Johan Werner the Younger. See: Rosell, Läckö slottskyrka, 59. 


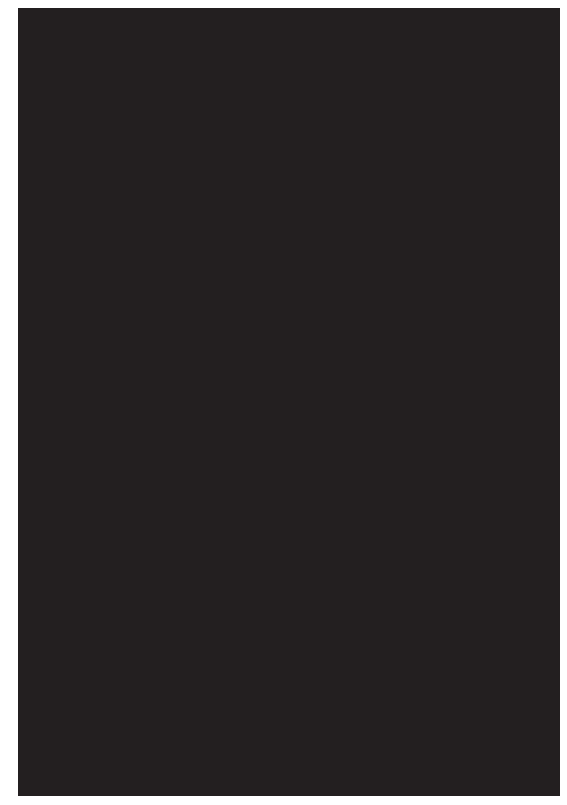

Fig. 8. Johan Johansson Werner, figure of "Ivsticia" on the tomb of Erik Göransson Ulfsparre and Beata Oxenstierna, 1631; Linköping Cathedral. Photo: Simon McKeown.

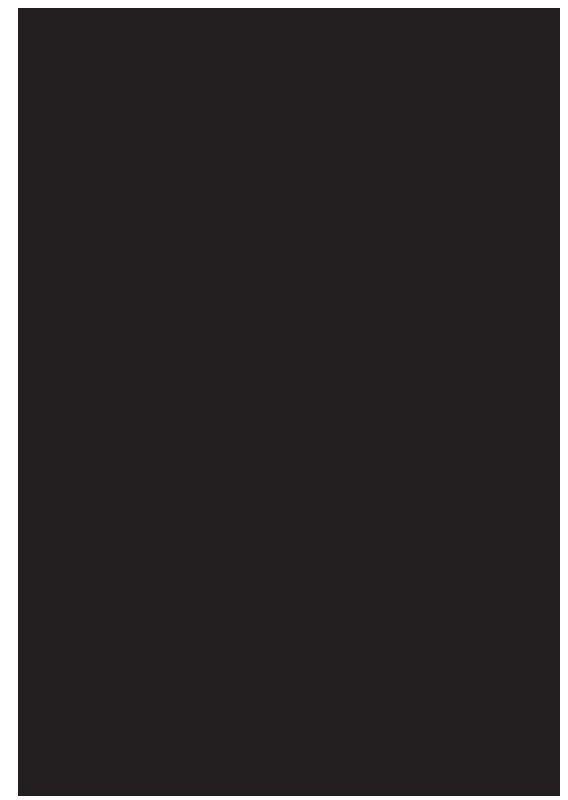

Fig. 9. Johan Johansson Werner, figure of "Fortitudo" on tomb of Erik Göransson Ulfsparre and Beata Oxenstierna, 1631; Linköping Cathedral. Photo: Simon McKeown.

progressed. Sometimes, there seems to be little operation of innovation or adaptation in these configurations, but in other cases there can be iconographic surprises. One such has been described by Peter Gillgren in his discussion of the monument in Dalby, Uppland, for Knut Posse by an unknown artist and dating from the $1660 \mathrm{~s} .{ }^{40} \mathrm{It}$ is a hanging mural epitaph replete with armorial achievements, lapidary panegyrics, and classical architectural motifs. Its staffage of sculpted figures consists of Fides, Prudentia, Iustitia and Veritas (Truth) set out in pairs flanking the monument and leading the eye up to the summit of the composition. There, remarkably, the eye falls not on the figure of the Risen Christ, as might have been expected, but upon the brazenly nude figure of Fortuna standing upon her ball. As Gillgren rightly says, the conventional Christian iconography is disrupted with the striking thought that all life is subject to the vagaries of Fortune, but that control can be wrest-

40 Peter Gillgren, “Skulpturen”, Barockens konst. Signums svenska konsthistoria 6 (Lund: Signum, 1997), 334-337. 
ed away from the dictates of Fate if the good man or woman follow the bidding of Virtue. ${ }^{41}$ Of course, we detect in this a reimagining of the representation of Fortuna set forward in Petrarch's De remediis utriusque fortunae, first published in 1366. In this dialogue, the writer argues for the imposition of human wisdom over the dictates of Fortune, an idea later condensed into the saw "Sapientia Fortunam" ("Wisdom conquers Fortune"). ${ }^{42}$ Seen in this light, Knut Posse's monument argues for the role of human agency in the control of Fortune, a Christianized reading of central ideas espoused by Machiavelli. ${ }^{43}$

Perhaps the highest achievement of Swedish allegorical sculptures of the Virtues came in the 1660s with a remarkable memorial to the commander, Lars Kagg (Fig. 10). ${ }^{44}$ Kagg was a veteran of the Thirty Years War, a career soldier who had first seen service as a young officer under Gustavus Adolphus, and who had played a part in the Swedish victory at Oldendorf in 1633 . He subsequently held a series of military and civilian posts that included a seat on the Council of War (Krigsråd), a member of the Council of State (Riksråd), and ultimately Field Marshal of the Realm. At his death in 1661, Kagg was mourned as a patriot and hero whose career had described a remarkable trajectory through Sweden's rise from marginal European kingdom to leading Protestant power. He was buried with due pomp in a ceremony in the Riddarholmskyrkan, and his coffin laid to rest a short distance from that of his early sponsor, Gustavus Adolphus.

The principal monument to Kagg's career cannot be found at the Riddarholmskyrkan, however. Instead, it was erected in the church of Floda in Södermanland, near Kagg's country seat of Fjellskäfte, a place that as early as the 1630s Kagg had projected as the site for a chap-

\footnotetext{
41 Ibidem, 336-337.

42 Cited as the personal device of Edward III of England: see Jacobus Typotius, Symbola divina et humana (Prague, 1601), 97-98.

43 See: Allan Ellenius, "Johannes Schefferus, Kristina Minerva och Fortuna Audax. En studie i politisk emblematic", Lychnos (1954-1955), 165-195, or in English translation, "Johannes Schefferus, Christina Minerva, and Fortuna Audax: A Study in Political Emblematics", The Emblem in Scandinavia and the Baltic, ed. by Simon McKeown and Mara R. Wade, Glasgow Emblem Studies 11 (Glasgow: Glasgow Emblem Studies, 2006), 75-102; Kristiina Savin, Fortunas klädnader: lycka, olycka och risk i det tidigmoderna Sverige (Lund: Sekel, 2011).

44 Concerning Kagg, see Svenskt biografiskst lexikon, vol. 20 (Stockholm: Norstedt, 1973), 563.
} 


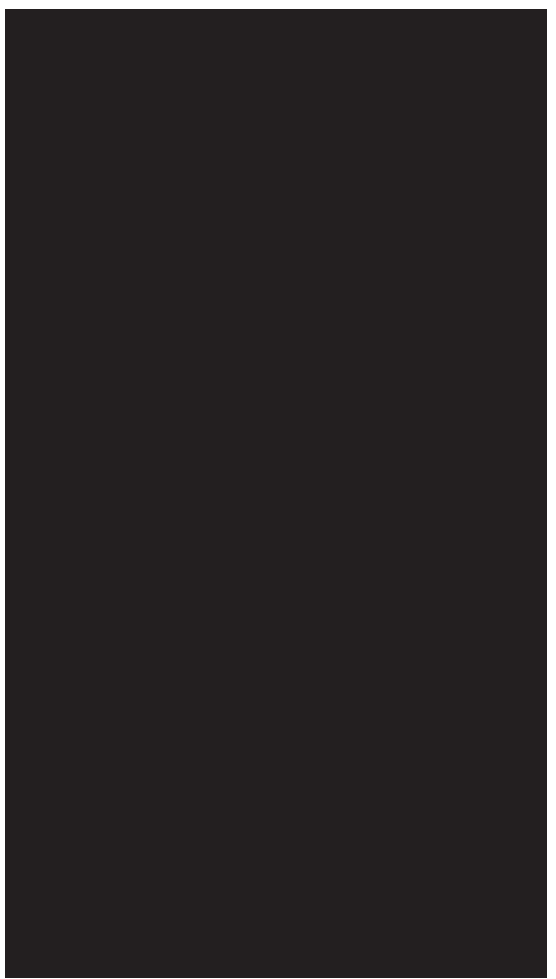

Fig. 10. Georg Günther Kraill von Bemberg, Portrait of Lars Kagg, tempera on canvas, 1623. Courtesy of Skokloster Castle. el dedicated to his memory and that of his wife, Agneta Ribbing. ${ }^{45}$ Kagg oversaw the expansion of the church in the 1630s when he paid for it to be doubled in size by the addition of a south nave as large as the medieval nave and chancel. Work on this was probably begun in $1637 .{ }^{46}$ After his death, in the early 1660s, the large and imposing Kaggska gravkoret was added onto the east gable of the church. Interestingly, the architect of this chapel was none other than Erik Dahlbergh, a shining light in the constellation of Swedish heroes of the Age of Greatness. Dahlbergh is remembered today chiefly for his unparalleled record of Sweden's noble buildings which he drew and engraved for the great work, Suecia antiqua et hodierna ${ }^{47}$ But Dahlbergh was also a significant figure in the Swedish military, Quartermaster General of all Swedish arms, Field Marshal, and Governor-General of Livonia. Among his many talents was a facility in architecture, and, as

45 For more on the Kagg Chapel, see Ellenius, “The Rhetoric of Virtue”; Robert Bennett, Floda kyrka. Sveriges kyrkor 205 (Stockholm: Almqvist and Wiksell, 1988), particularly, 33-40; Mårten Liljegren, Stormaktstidens gravkor (Stockholm: Norstedt, 1947), 196-201; and Torbjörn Fulton, "Stuckaturen", Barockens konst. Signums svenska konsthistoria 6 (Lund: Signum, 1997), 290-292.

46 Bennett, Floda kyrka, 117, 137.

47 For a biographical sketch of Dahlbergh, see "Dahlberg, Erik", Svenskt biografiskt handlexikon, vol. 1 (Stockholm: Albert Bonnier, 1906), 208-210. Broader consideration of his career can be found in Stormaktstid. Erik Dahlbergh och bilden av Sverige, ed. by Leif Jonsson (Skövde: Stiftelsen Läckö institutet, 1992); and on his Suecia antiqua et hodierna, Börje Magnusson, Att illustrera fäderneslandet. En studie i Erik Dahlberghs verksamhet som tecknare, Acta Universitatis Upsaliensis, Ars Suetica 10 (Uppsala: Almqvist and Wiksell, 1986). See also Börje Magnusson, "Sweden Illustrated. Erik Dahlbergh's "Suecia Antiqua et Hodierna" as a Manifestation of Imperial Ambition", Baroque Dreams: Art and Vision in Sweden in the Era of Greatness, ed. by Allan Ellenius, Acta Universitatis Upsaliensis, Figura Nova 31 (Uppsala: Uppsala Universitet, 2003), 32-59. 


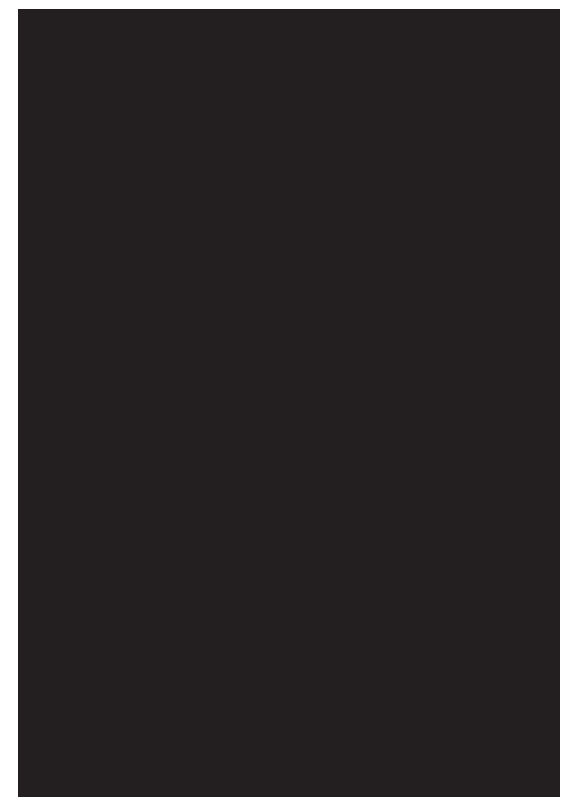

Fig. 11. Carlo Carove, figure of „Fortitvdo“, Kagg Memorial Chapel, stucco, 1660s; Floda Church, Södermanland. Photo: Courtesy of Anette L, www.anettemcl.se.

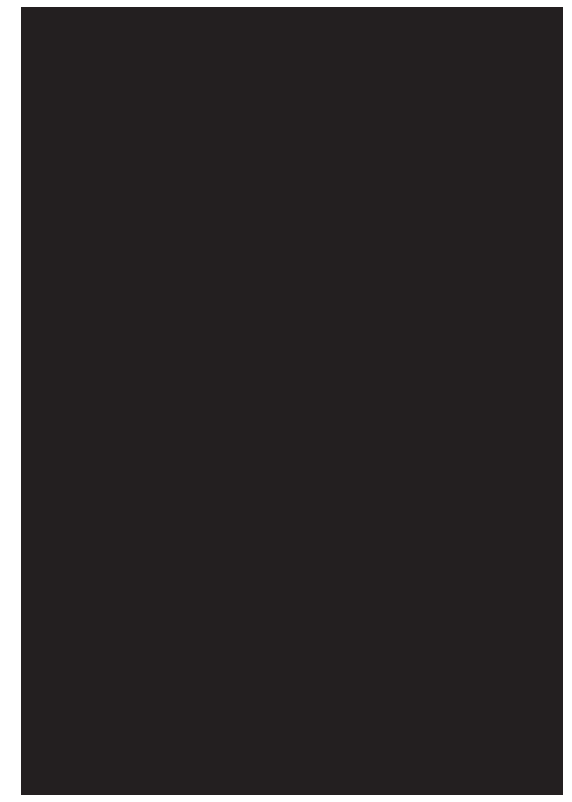

Fig. 12. Carlo Carove, figure of „Prvdentia“, Kagg Memorial Chapel, stucco, 1660s; Floda Church, Södermanland. Photo: Courtesy of Anette L, www.anettemcl.se.

has been noted elsewhere, an understanding of emblematics. ${ }^{48}$ Whether or not Dahlbergh had a determining hand in the decorative programme within the chapel at Floda is unknown, but it is intensely inscribed with emblematic and allegorical ideas. In any case, Dahlbergh is certain to have had close involvement with the artist responsible for the décor of the interior, the Italian stucco master, Carlo Carove (+1697), who had been employed by the Dowager Queen Hedvig Eleonora at her palace of Drottningholm in the late 1660s. Carove probably began his work at

48 Simon McKeown, "Death and a Maiden: Memorial Engravings from the Circle of Erik Dahlbergh", Emblematica 14 (2005), 417-439. 
Floda in the second half of the 1660s: the whole space is signed and dated by him in $1667 .{ }^{49}$

His work at Floda is an extraordinary confection of elaborated Baroque virtuosity, and Carove shows his skill in combining architectural elements, proclamatory cartouches, genii and putti, swags, garlands and trophies, armorial testimonies and symbols of mourning. In all this, a key role is given to eight life-sized emblematic figures set into niches and modelled in remarkably high relief. These stand at intervals around the room and represent, from the left, Honor (Honour), Valor (Courage), Magnanimitas (Magnanimity), Fortitudo, Aeternitas (Eternity), Prudentia, Vigilantia (Vigilance) and Fama (Good Reputation) (Figs. 11 \& 12). As Robert Bennett has observed, these allegorical figures can be interpreted as comments upon Kagg's military character, his sense of chivalry, his powers of endurance, his watchfulness and wisdom, his physical courage, and his unblemished fame. The allegorical figure of Magnanimitas perhaps requires a little more exposition (Fig. 13). This Virtue is seemingly figured as a woman in classical robes standing with elegant contrapposto and with her right breast bared. She stands seemingly oblivious to a lion which emerges behind her to her left, her sinister side. For the didaxis of Carove's conceit to be properly read, it needs to be understood that the allegorical representation of Magnanimitas in this figural group resides in the lion, not the woman. She is, in fact, Diana, goddess of chastity and the hunt, as revealed by the crescent moon worn on her brow. The association of the lion with generosity of heart and mercifulness towards the weak stems back into antiquity and formed one of the legends surrounding Alexander the Great. ${ }^{50}$ After the Battle of Issus in $333 \mathrm{BC}$, Alexander, who in his personal iconography encouraged his identification with the lion, astonished onlookers with his nobility of spirit in exercising restraint when the wife and daughters of his Persian enemy, Darius III, fell into his hands. His gracious treatment of

49 Concerning Carove, see Svenskt biografiskt lexikon, vol. 7 (Stockholm: Albert Bonnier, 1927), 607. Allan Ellenius speculated that Carove may have been either summoned from Italy by Hedvig Eleonora to work on Drottningholm, or had been persuaded north by Dahlbergh during the latter's sojourn there in the early 1650s: see Ellenius, “The Rhetoric of Virtue”, 516. Concerning Hedvig Eleonora's role as a cultural sponsor, see the recent study by Lisa Skogh, Material Worlds: Queen Hedwig Eleonora as Collector and Patron of the Arts, Bidrag till Kungl. Vetenskapsakademiens historia 44 (Stockholm: Center for the History of Science at the Royal Swedish Academy of Sciences, 2013).

50 For a fuller discussion of this iconography, see Simon McKeown, "Materiell kultur: Den emblematiska kontexten till ett kavalleristandar från 1600-talet i Armémuseum", Meddelande. Armémuseums årsbok 61 (2003), 9-49. 


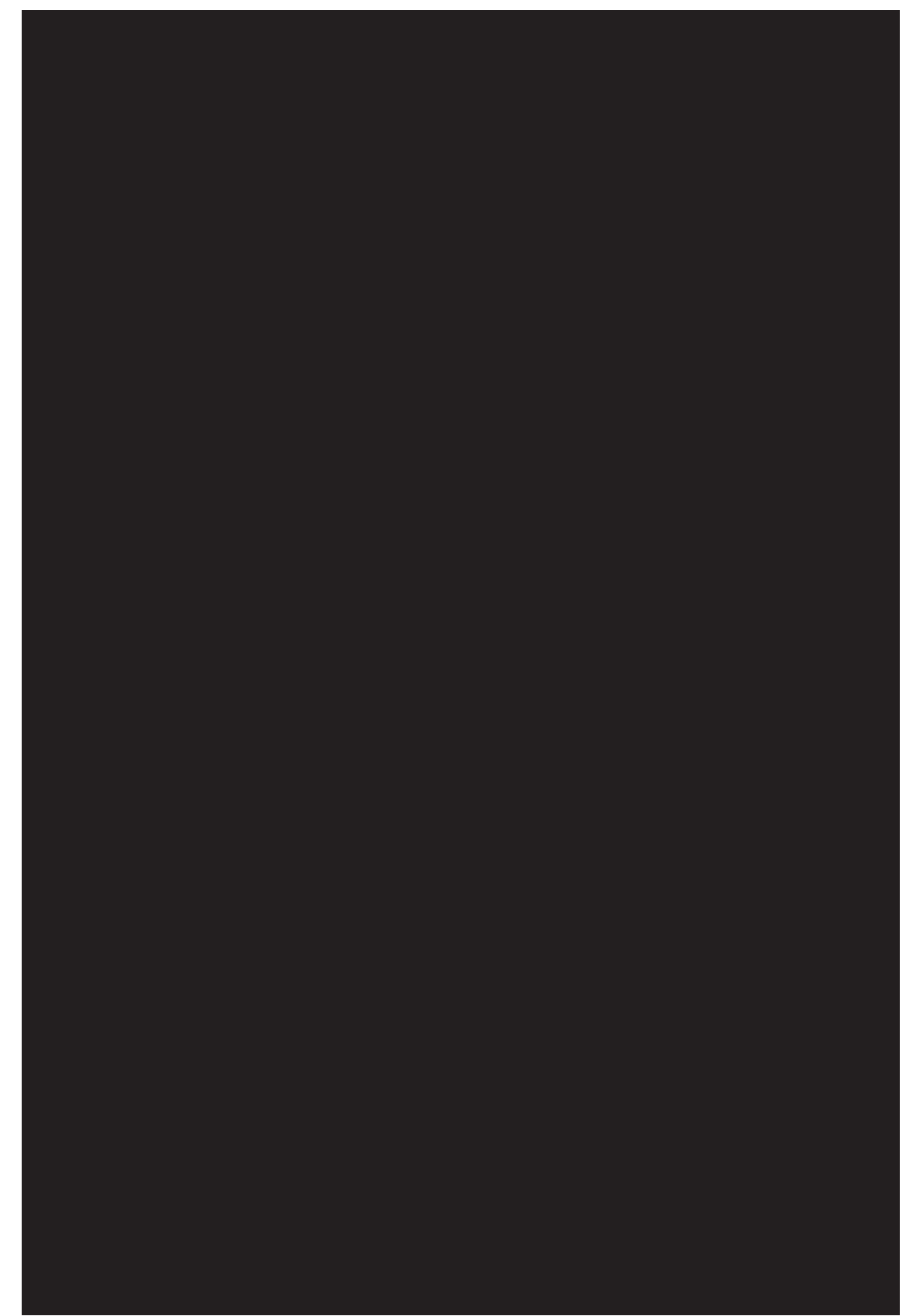

Fig. 13. Carlo Carove, figure of „Magnanimitas“, Kagg Memorial Chapel, stucco, 1660s; Floda Church, Södermanland. Photo: Courtesy of Anette L, www.anettemcl.se. 
his high-ranking captives established his reputation for magnanimity, and furthered the lion's association with that quality. This tradition, promulgated in such canonical works as Plutarch's Vita Alexandri, was preserved in the medieval bestiaries, and continued in the animal lore of emblem books. ${ }^{51} \mathrm{~A}$ well-known example can be found in Guillaume de la Perrière's Morosophie of 1553. There, in Emblem 27, the lion resists the yapping of an impertinent pup, as the soldier magnificently foregoes violence against the weak and defenceless: as the emblematic scriptu$\mathrm{ra}$ states, "As the lion thinks it wrong to try his strength with mighty muscles against the fearful puppy, so tough Mars disdains to knock the weakling coward down and searches always for the strong". ${ }^{52}$ So what role does the goddess Diana play in the figural group at Floda? One of the manifestations of the lion's magnanimity according to these traditions was its fearlessness before hunters, and its preference to reveal itself to the hunter rather than to cower away. ${ }^{53}$ Thus it is that we see the lion break its cover from behind the goddess of the hunt. Carove, desirous of representing Kagg's generosity of spirit, suggests it through the magnanimous lion, but ingeniously preserves the integrity of his wider artistic conception by pairing the creature with a life-sized figure in classical garb.

Carove's panegyric programme for Kagg extends to the very roof, because arching over the memorial chapel is further rich ornamentation in the vaults, where we see the allegorical figures of "Iustitia", "Pietas", "Temperantia" and "Religio Christiana" in relief set into the cells of the spandrels (Fig. 14). Each of these figures is framed within a strapwork cartouche bordered by martial trophies; the figures show gracious contrapposto for example, the type for Temperance who rests a proprietorial

51 Plutarch's Elizabethan translator, Sir Thomas North, marks this point of his text with the marginal gloss, "The clemency of Alexander unto the captive Ladies": see Plutarch, The Lives of the Noble Grecians $\&$ Romans, compared together... trans. by Sir Thomas North (1579; London: Abraham Miller, 1657), 567. 52 "Ut timidum validis catalum contundere nervis/Esse nefas reputat fortis in arma Leo:/Sic animo fractos rigidus prosternere Mavors/Respuit, et fortes viribus usque petit": Guillaume de la Perrière, Morosophie (Lyons: Macé Bonhomme, 1553), sig. E7v. Interestingly, the elements of this emblem have been discovered among the elaborate allegorical carvings on Gustavus Adolphus' flagship Vasa, raised from the seabed in 1961. See: Hans Soop, The Power and the Glory: The Sculptures of the Warship Wasa (Stockholm: Kungl. Vitterhets Historie och Antikvitets Akademien, 1986), 161-164.

53 See: Cesare Ripa, Baroque and Rococo Pictorial Imagery: The 1758-60 Hertel Edition of Ripa's Iconologia with 200 Engraved Illustrations, ed. by Edward A. Maser (New York: Dover, 1971), no. 64. 
Fig. 14. Carlo Carove, figure of „Temperancia“, vaults of the Kagg Memorial Chapel, stucco, 1660s; Floda Church, Södermanland. Photo: Courtesy of Anette L, www.anettemcl.se.

hand on the head of her expository elephant. ${ }^{54}$ Carove's allegoresis is clear: the chief virtues that governed Lars Kagg were his adherence to justice, his self-control, and his unimpeachable piety. Just as the assembly of heraldic achievements testify to his pedigree and social advantage, so these emblems attest to his innate ornaments of character.

One of the important aspects of the Kagg Chapel at Floda is the evidence it bears of articulacy in the semiotic language of emblematics, and thereby connectivity with the wider intellectual currents of the

54 The iconography of the elephant, a beast that never eats more than it requires, is set out in Ripa's exposition of the allegory of Temperance: see Cesare Ripa, Iconologia (Siena: Heirs of Matteo Florimi, 1613), 296-297. 


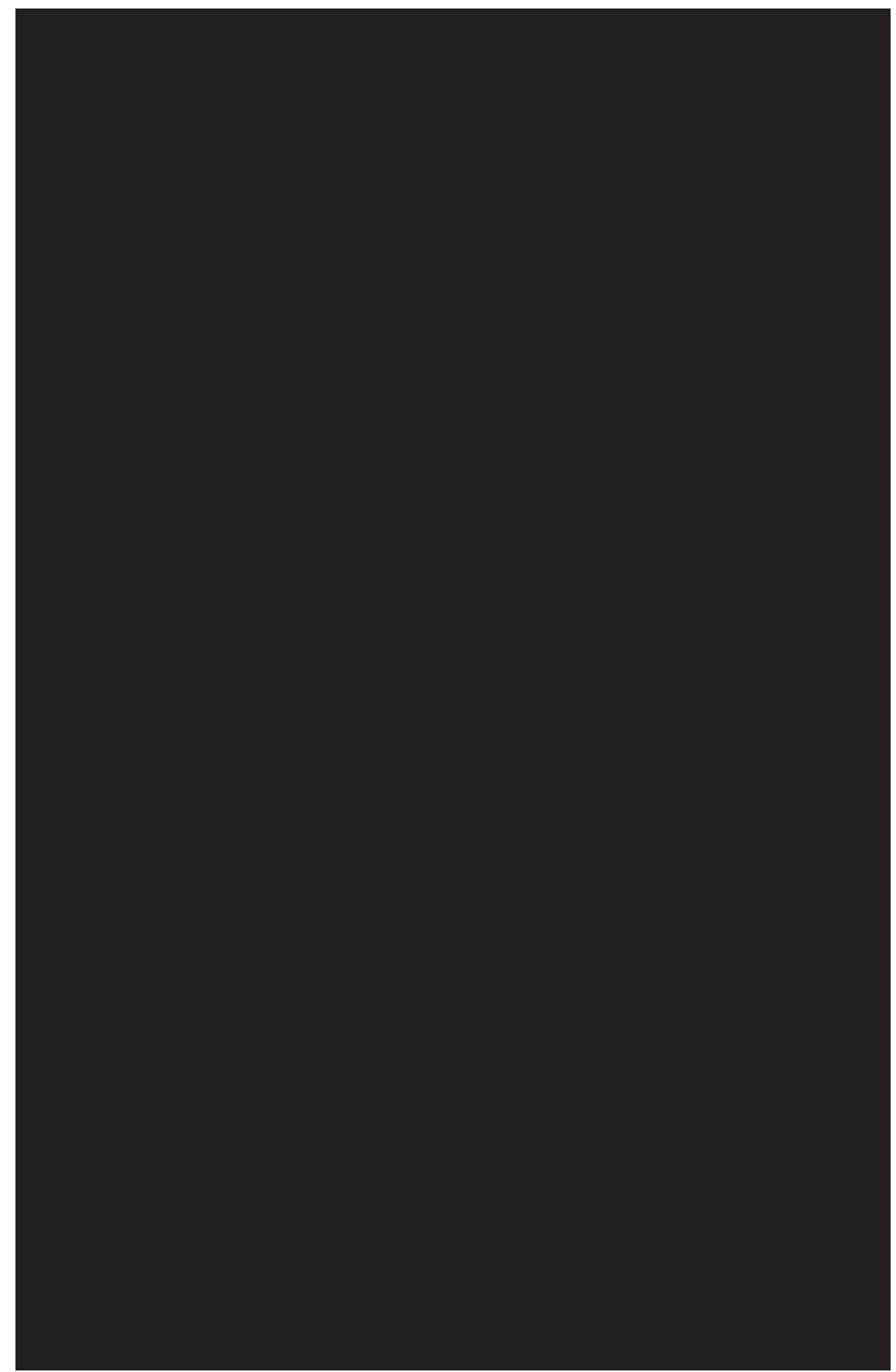

Fig. 15. Hendrick Goltzius, Jacob Matham and Jan Saenredam, „Fortitudo“, engraving, 1593. Photo: Courtesy of the Department of Prints and Drawings, The British Museum. 
seventeenth century, and of engagement with ideas and values that had emerged in the Italian Renaissance. It is not possible to dismiss Carove's allegorical figures at Floda as unthinking or unmediated borrowings from a pattern book. In truth, the palimpsests of several of Carove's figures can be traced to the conventions set out in Cesare Ripa's Iconologia, that great handbook of hypostatic allegory and prosopopoeia that was to exert such influence in the fine and applied arts far into the nineteenth century. But other figures in his programme appear to draw inspiration from earlier graphic representations of allegorical ideas, notably from the great series of Virtues designed by Hendrick Goltzius and engraved by Jacob Matham and Jan Saenredam in the 1590s (Fig. 15). ${ }^{55}$ Carove, it seems, has looked to a wide repertoire of prototypes and patterns to fashion his schema at Floda, and perhaps the very idea of the allegorical figures placed in niches at intervals around the space had its roots in an Italian decorative schema, possibly Perino del Vaga's famous frescos for the Sala Paolina in Castel Sant'Angelo in Rome. ${ }^{56}$ But what the chapel at Floda makes clear is that there was an expectation that such displays would be understood, that there was an audience capable of making sense of recondite ideas expressed through codified sign systems. It was doubtless thought that this audience might comprise of members of the elite with access to classical knowledge and the mens emblematica.

But the Kagg Chapel should also be seen as an expression of a wider repertoire of Baroque spectacle, part of the rhetorical world of performance where allegorical characters come to speak of their central subject like the personifications in a masque, that quintessentially seventeenth-century amalgam of theatre and performance that had taken hold of the Swedish court during the reign of Queen Christina. ${ }^{57}$ Just as those productions, penned by luminaries like Georg Stiernhielm, had glorified and extolled the person of the queen through allegorical abstractions, so Carove's cast of stuccoed personifications magnified the

55 For a discussion of these series, see Hans-Martin Kaulbach and Reinhart Schleier, "Der Welt Lauf", Allegorisches Graphikserien des Manierismus (Stuttgart: Staatsgalerie, 1997), 25-62.

56 The programme was carried out between 1545 and 1547. See: Sydney J. Freedberg, Painting in Italy, 1500-1600 (Harmondsworth: Penguin, 1970), 171-172.

57 See F.J. Fielden, "Court Masquerades in Sweden in the Seventeenth Century I", The Modern Language Review 16.1 (1921), 47-58; and F.J. Fielden, "Court Masquerades in Sweden in the Seventeenth Century II”, The Modern Language Review 16.2 (1921), 150-165. 
moral and spiritual attainments of Kagg. ${ }^{58}$ Where in mundane reality Kagg, like anyone else, manifested myriad behaviours - from cordiality to peevishness, exuberance to indolence, frivolity to profundity - in his memorial chapel he is forever transfigured and fixed in an attitude expressive only of moral seriousness and probity. The flux of conflicting emotions that characterises human existence is stilled through the medium of sculpture into an attitude of moral rectitude and spiritual repose. These qualities, when allegorised as Virtues, become external figurations of invisible qualities innate to Kagg. We can link this with the wider rhetoric of Baroque mourning in Sweden. Kagg's funeral procession was a major spectacle for the Stockholm citizenry as it made its way to the cathedral to the sound of trumpets and kettle-drums. ${ }^{59}$ This must have made for a stirring martial performance, but the impermanence of music offered a parallel with the brevity of life, as evidenced by countless seventeenth-century vanitas paintings of musical instruments. It was in the search for a solution to this problem of transience that Carove included trumpets and kettle-drums in the decorative stuccowork at Floda: here, they helped frame a military memorial for a field marshal, but they also offered an echo of Kagg's heroic action and public acclamation in life. In a similar way, the personal qualities possessed of Kagg formed the theme of the lengthy funeral sermon, or gravtal, which eulogized his career in triumph and adversity. ${ }^{60}$ But such encomia are also temporary performances, lost on the air as soon as they are spoken. This, too, was a subject of vanity. What, then, was the purpose of the Kagg Chapel, a mortuary monument without the bodies of the man and woman it celebrated? Here, in this dynastic space, room opened up for a kind of built eloquence impossible in the Riddarholmskyrkan; the church at Floda was a place of memory, an architectural articulation of the enduring fame of Lars Kagg and his wife. The words of the preach-

58 It is worth noting that Stiernhielm's greatest literary achievement was his Hercules, published in Uppsala in 1658, a moral-didactic poem that made wide use of allegorical abstractions, and whose titlepage, designed and engraved by Stiernhielm himself, showed the youthful Hercules caught between the choices offered to him by Dame Virtue and Dame Vice. See Axel Friberg, Den Svenske Herkules. Studier i Stiernhielms diktning (Lund: Håkan Ohlsson, 1945).

59 Ellenius, "The Rhetoric of Virtue", 514.

60 As was customary for a man of noble rank, Kagg's funeral sermon, including a moralized biography known as the "Personalia", was printed after his burial. See: Hans sahl: höchgrefl: excell:tz herr ricksmarckens höchvälborne grefve Lars Kagg personalia och lickproces A:o 1662 den 8 junii från S:t Jacob och till Ridderholms kyrckio uthi Stockholm... (Np: npub, nd). For a study of the conventions of the early modern Swedish funeral sermon, see Göran Stenberg, Döden dikterar. En studie av likpredijningar och gravtal från 1600- och 1700-talen (Stockholm: Atlantis, 1998). 
er long fallen silent, Carove's allegorical figures present to posterity in perpetuity the ongoing, enduring and ultimately defining essence of Kagg's character, distilled into the forms of the universal Virtues long sealed and sanctioned by classical and Christian tradition. The abstractions serve to apotheosize Kagg so his reputation crystallizes into that of a man whose sovereign temper was shaped alone by Virtue.

\section{CONCLUSION}

What had generally been an iconographical resource at the disposal of immigrant artists and craftsman plying their trade in Sweden at some stage became adopted and naturalized among Swedish sculptors working in humbler environments and with more modest materials than the marble and alabaster of aristocratic tombs. Evidence for this is spread widely across the older churches of Sweden, but, by way of conclusion, let us consider the little church of Säby near Tranås in northern Småland, a picturesquely pastoral spot today, but a place remote in every sense in the late seventeenth century. Here, on the west wall of the church stand four polychrome wooden sculptures dating from the latter part of that century, all evidently once from the same sculptural group. All four figures are female and stand on consoles, fragments of a larger architectural composition, an altar retable, now lost. The four women depicted in the sculptures are personifications of the Virtues; three can be identified as Temperantia, Fortitudo and Prudentia by their attributes (Figs. 16, 17). The fourth figure has suffered damage, but the heart in her right hand suggests that she configures Pietas. The sculptures were carved and set up in the church in 1686 by a provincial sculptor and painter, Jöran Bundij, who came from Eksjö, some thirty kilometres to the south of Säby. The craftsmanship performed by Bundij stands towards the end of a long and venerable tradition of Scandinavian polychrome wood sculpture (målad träskulptur) that characterises some of the high achievements of Gothic art in the Swedish Middle Ages. ${ }^{61}$ But while, the figures at Säby fall far short of the execution of the finest work of earlier centuries, they

61 The absence of iconoclastic fervour around the Swedish Reformation resulted in the preservation of numerous exemplars of medieval sculpture, unlike the wholesale destruction wrought on devotional art in England and Flanders. In 1650, the Swedish Church Ordinance set forward specific measures to protect church ornaments from molestation. See Bengt Thordeman, Medieval Wooden Sculpture in Sweden, 1. Attitudes to the Heritage (Stockholm: Museum of National Antiquities, 1964), 7-22. See also: Ångström, Altartavlor från renässans och barock, 31-34. 


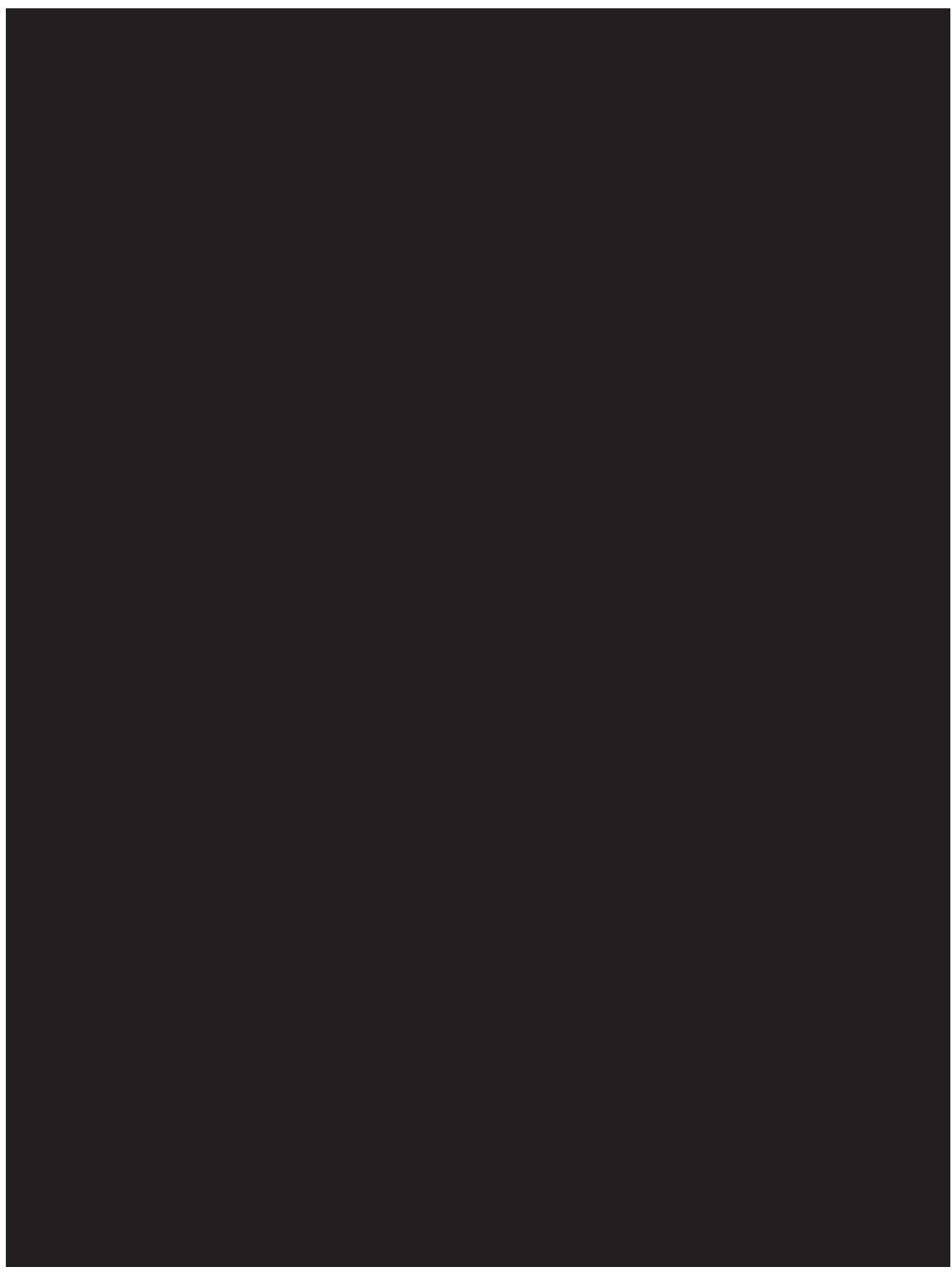

Fig. 16. Jöran Bundij, figure of Temperance, polychrome wood, 1686; Säby Church, Småland. Photo: Simon McKeown 


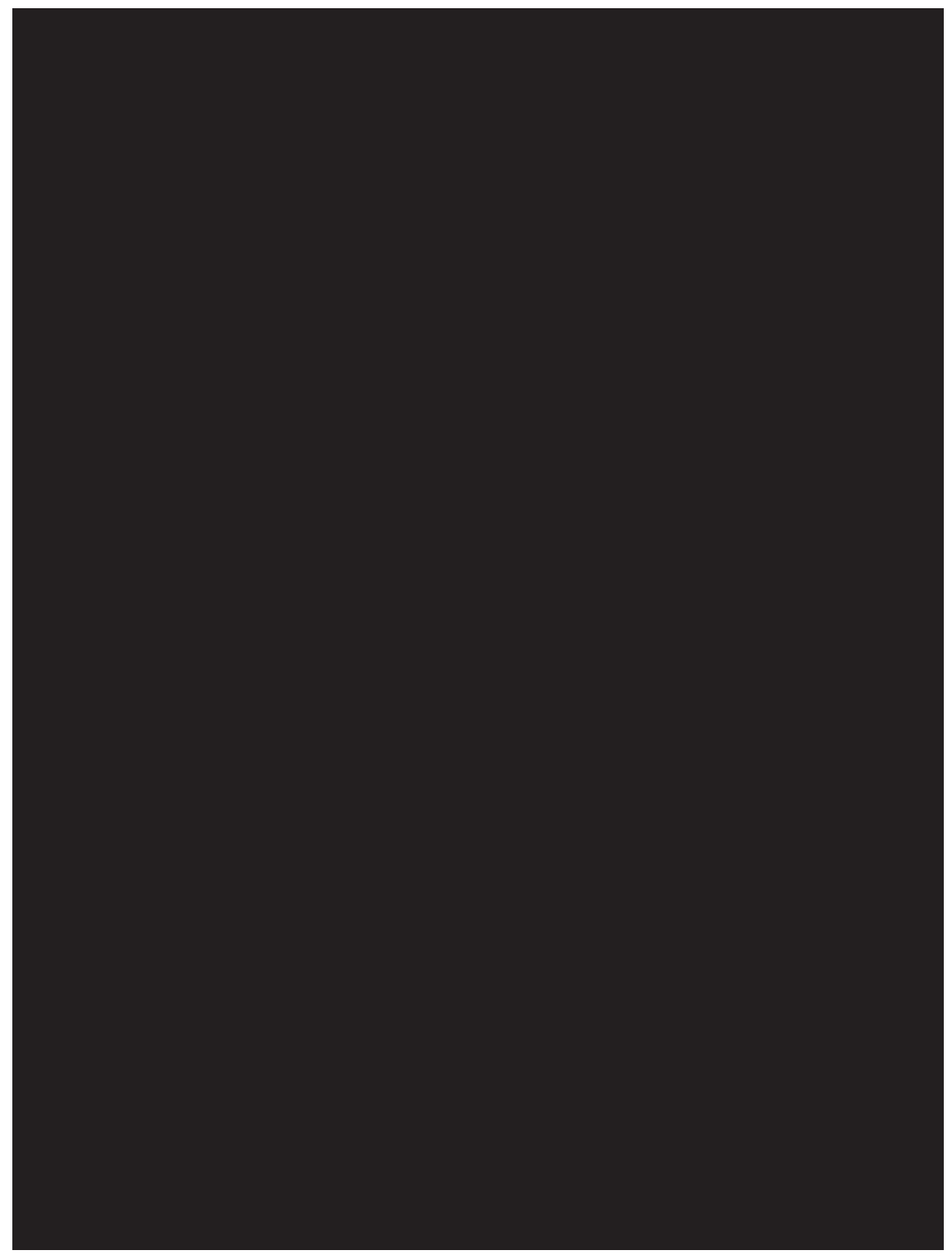

Fig. 17. Jöran Bundij, figure of Fortitude, polychrome wood, 1686; Säby Church, Småland. Photo: Simon McKeown. 
should be seen as local manifestations of themes of very long pedigree, themes which predate the Christian iconography of Saviour and saints that more typically characterizes older Scandinavian polychrome carving. ${ }^{62}$ The synthesis of these classical tropes into the iconography of an ecclesiastical space shows the remote operation of the Renaissance assimilation of the allegorizing process of prosopopoeia. And while such figures would be unsurprising within the context of wider European church interiors, they are novel elements in the iconographical repertoire of Swedish devotional sculpture. It is striking indeed to see these classical humanist and Renaissance figures from the pages of Ripa appearing in a small, rural church amid the rugged forests of Småland. The polychrome carvings at Säby are fragmentary evidence of the wider purchase of the iconography of the Virtues in late seventeenth-century Sweden. Up at court, the painter David Klöcker Ehrenstrahl was making full use of such personifications in his extensive programmes of picture production for royal residences; equally, the sculptor Nicolas Millich was to execute marble figures of the Muses for the main staircase at Drottningholm, and there is little doubt that he did so in mind of Artus Quellinus the Elder's famous series of Virtues from Amsterdam Town Hall. ${ }^{63}$ But in rural churches, something of this taste for abstraction meant that the Virtues, Cardinal and Theological, could be adopted as readily as the Four Evangelists or figures of the Patriarchs as fitting adornment of pulpit or retable. But it was not until the mid-eighteenth century that Swedes without skill in languages could read about the rich meanings inherent in the Renaissance's codifications and allegories. In 1746, a pastor of the Jönköping regiment, Anders Lallerstedt, a man fired by a compulsion to offer handbooks on recondite subjects, published his Compendium ethicum, eller Kort inledning til dydge- eller sedo-läran. ${ }^{64}$ This work, which takes its tone from the moral disquisitions

62 For this tradition, see inter alia, Carina Jacobsson, Höggotisk träskulptur i gamla Linköpings stift (Visby: Odins förlag, 1995); Peter Tångeberg, "Träskulpturens tekniker", Renässansens konst, Signums svenska konsthistoria 5 (Lund: Signum, 1996), 368-377; and Peter Tångeberg, Retabel und Altarschreine des 14. Jahrhunderts. Schwedische Altarausstattungen in ihren europäischen Kontext (Stockholm: Kungl. Vitterhets Historie och Antikvitets Akademien, 2005).

63 Concerning Ehrenstrahl, see Allan Ellenius, Karolinska bildidéer, Acta Universitatis Upsaliensis, Ars Suetica 1 (Uppsala: Almqvist and Wiksell, 1966); for Millich, see Karl Erik Steneberg, "Le Blon, Quellinus, Millich and the Swedish Court "Parnassus"”, Queen Christina: Documents and Studies, ed. by Magnus von Platen, Analecta Reginensia 1, Nationalmusei skriftserie 12 (Stockholm: Norstedts, 1966), 332-364.

64 Anders Lallerstedt, Compendium ethicum, eller Kort inledning til dydge-eller sedo-läran... (Stockholm: P.J. Nyström, 1746). 
of the German professor and poet, Magnus Daniel Omeis, was illustrated with 31 full-page xylographs strongly influenced by the iconologies of the seventeenth century, above all that of Ripa. With each woodcut printed recto facing a page of descriptive exposition, Compendium ethicum was a vernacular vade mecum by which Swedes could access the encryptions of the classical and Renaissance imagination. The plates, cut from drawings by the Stockholm illustrator, C. J. Beckerstedt, were to later re-surface in the 1820s in two cheaply produced publications which were little more than run-offs of the woodblocks fronted with title-pages suggestive of the catch-penny nature of the enterprise. These chapbooks were presented as Dygde-och sedo-lärans sinnebilder. ${ }^{65}$ In this form, found among the gallery of "emblems of the virtues and moral lessons", we can perhaps finally say that the figures of Spes, Fortitudo, Iustitia, Temperantia and the rest, lifted themselves down from the lofty gables of Vasa castles and aristocratic tombs and began to circulate freely in the streets of nineteenth-century Sweden. ${ }^{66}$

Simon Mckeown: Configuring Virtue: The Emergence of Abstraction, Allegoresis and Emblem in Swedish Figural Sculpture of the Seventeenth Century

Keywords: Allegory; Cardinal Virtues; Theological Virtues; Emblem Studies; Renaissance and Baroque Sculpture; Swedish Church Decor

\section{SUMMARY:}

This article concerns evidence of Renaissance cultural forms finding purchase in the visual arts of early-modern Sweden, specifically as ex-

65 For Lallerstedt and the later use of Beckerstedt's plates, see Simon McKeown, “The Emblem in Scandinavia", Companion to Emblem Studies, ed. by Peter M. Daly, AMS Studies in the Emblem 20 (New York: AMS, 2008), 340.

66 The author is grateful to a number of individuals and institutions in the writing of this article, notably Prof. Dr. Ojārs Spārītis of the Latvian Academy, Bengt Kylsberg of Skokloster Castle, and the staffs of the libraries of the Warburg Institute, University of London, the Royal Library, Stockholm, the Special Collections at the University of Glasgow, and Marlborough College. 
pressed in the figural sculpture of the seventeenth century. Traceable to stylistic innovations introduced by migrant stone-carvers from the Netherlands, new thematic elements from the realm of humanistic abstraction became established tropes within the native sculptural tradition. Taking figural representations of the Cardinal and Theological Virtues as an area of particular focus, the article demonstrates how these traditional topoi were for the first time naturalized as familiar elements in the decorative programmes of churches and memorial chapels. Their deployment in such contexts can be seen as evidence of a widening of the visual repertoire in the light of European cultural developments, and a new consciousness of the rhetorical power of persuasio among the commissioning patrons of such works from the emerging political and cultural elite.

CV:

Dr. Simon McKeown is Head of History of Art and Keeper of Rare Books at Marlborough College, UK. He specializes in the study of emblematics, particularly in the context of the fine arts and of Sweden. His books include the monograph Emblematic Painting from Sweden's Age of Greatness: Nils Bielke and the Neo-Stoic Gallery at Skokloster (2006), and the edited volumes The Emblem in Scandinavia and the Baltic (with Mara Wade, 2006); Reading and Writing the Swedish Renaissance (Special Number of The Journal of Renaissance Studies, 2009); The International Emblem: From Incunabula to the Internet (2010); and Otto Vaenius and his Emblem Books (2012). He sits on the advisory boards of the Society for Emblem Studies and of the journal Emblematica, and is one of the editors of the Imago Figurata series for Brepols publishers. 